\title{
SIX OF ONE IS NOT A DOZEN OF THE OTHER: A REEXAMINATION OF WLLIAMS v. FLORDA AND THE SIZE OF STATE CRIMINAL JURIES
}

\author{
ROBERT H. MILLER $†$
}

\begin{abstract}
The quality of social science scholarship displayed [in the Court's decisions on jury size] would not win a passing grade in a high school psychology class.
\end{abstract}

I have experienced more shocks and surprises from the six-man jury...than I experienced in all my previous 13 years combined.... When I speak of shocks and surprises, I refer only to those instances when every lawyer in the courtroom, including the judge, was flabbergasted [by the verdict]. ${ }^{2}$

\section{INTRODUCTION}

In Williams v. Florida, ${ }^{3}$ the Supreme Court overturned nearly eight hundred years of settled jurisprudence ${ }^{4}$ when it held that the Sixth Amendment guarantee to trial by jury ${ }^{5}$ did not require that the constitutionally mandated jury be composed of twelve members. ${ }^{6}$

† B.A. 1993, Yale University; J.D. Candidate 1998, University of Pennsylvania. This Comment is dedicated to the great teachers who have touched and influenced my life: Connie Scully, Millicent Hussey, and Selma Naccach-Hoff at Manchester Central; Gene Clark III and Tom Giggi at Belknap; Dorothy Singer, Kelly Brownell, and Bob Abelson at Yale; Frank Goodman, Bruce Mann, Kim Lane Scheppele, Pamela Harris, and Seth Kreimer at the University of Pennsylvania Law School; S.D., for always believing in me; and most of all, my parents, Robert and Monique Miller, whose many sacrifices, love, and care have made everything possible.

${ }^{2}$ Michael J. Saks, Ignorance of Science Is No Excuse, TRIAL, Nov.-Dec. 1974, at 18, 18.

2 Judge Victor J. Baum, The Six-Man Jury-The Cross Section Aborted, 12 JudGES' J. 12, 12 (1973).

399 U.S. 78 (1970).

4 See Williams, 399 U.S. at 122 (Harlan, J., concurring in judgment) ("The Court ... strip [s] off the livery of history from the jury trial ....").

${ }^{5}$ The Sixth Amendment reads, in pertinent part, "[i]n all criminal prosecutions, the accused shall enjoy the right to a speedy and public trial, by an impartial jury of the State and district wherein the crime shall have been committed." U.S. CONST. amend. VI.

${ }^{6}$ See Williams, 399 U.S. at 102 ("[T]he fact that the jury at common law was composed of precisely 12 is a historical accident, unnecessary to effect the purposes of the jury system...."). In Williams, the Court decided that a defendant's Sixth 
Despite the Court's highly questionable conclusions about the legislative history of the twelve-person jury requirement underlying the Sixth Amendment, and the Court's "remarkable incompetence" in interpreting and applying social-science findings to support its departure from the twelve-person jury standard, Williams and its progeny have never been reexamined. As a result, this line of cases continues to support the premise that six- and twelve-person juries are functionally equivalent, when in truth, modern social-science research finds exactly the opposite.

This Comment revisits the Court's initial decision in Williams, aided by a quarter-century of additional research and information, to illustrate that the case was wrongly decided. First, this Comment will demonstrate that historians reliably have traced the logical development of the twelve-person jury back to the Middle Ages in England, showing it to be anything but a "historical accident." ${ }^{8}$ It will also illustrate how Revolutionary-era legislative history strongly indicates the Framers' intent to retain the twelve-person jury standard in criminal trials.

More significantly, this Comment will reveal and discuss the critical ways in which the Court's misinterpretation and misapplication of social-science research in Williams and its progeny triggered the "unthinkable" dismantling of an irrevocable constitutional cornerstone. A comprehensive review of the modern psychological literature will demonstrate that the functional differences between six- and twelve-person juries: (1) implicate the Williams Court's statements about the jury's essential functions, and (2) may affect the outcome of many criminal trials. Finally, this Comment will argue that as a result of these critical functional differences, Williams and its progeny should be overruled, and the size of all state and federal criminal juries restandardized to twelve members in all non-petty criminal cases.

The system of trial by jury is again at the forefront of America's collective consciousness; a subcommittee of the Judicial Conference of the United States ${ }^{10}$ is considering a change to the Federal Rules of

Amendment rights, as made applicable to the states via the Fourteenth Amendment, see Duncan v. Louisiana, 391 U.S. 145, 147-58 (1968), are not violated when a state provides a six-person jury instead of a twelve-person jury.

${ }^{7}$ Saks, supra note 1 , at 19.

${ }^{8}$ Willams, 399 U.S. at 102.

${ }^{9}$ Id. at 122 (Harlan, J., concurring in judgment).

${ }^{10}$ The Judicial Conference, a 27-judge panel headed by the Chief Justice of the United States, proposes rule changes directly to the Supreme Court. If approved by 
Civil Procedure that would require the impaneling of twelve-person juries in all civil cases tried in federal courts." The Federal Rules of Criminal Procedure already require twelve-person juries, ${ }^{12}$ but jurysize requirements in state courts, which hear the vast majority of criminal cases, remain widely disparate. ${ }^{13}$ Additionally, the recent trials of Rodney King and O.J. Simpson thrust discussions about juries and jury functions back into the spotlight and provoked many questions about the representative nature of juries, the quality of deliberations, the influence of minority jurors, and the general integrity of the jury process. With such considerations in mind, it is both timely and appropriate to reexamine the Court's controversial treatment of jury size in Williams and its progeny.

\section{A REVIEW OF SUPREME COURT RULINGS ON JURY SIZE}

In Duncan v. Louisiana, ${ }^{24}$ the defendant was convicted of simple battery after he was denied a jury trial pursuant to a provision in the Louisiana Constitution that limited jury trials in criminal actions to cases in which capital punishment or imprisonment at hard labor might be imposed. ${ }^{15}$ Duncan, who was sentenced to sixty days imprisonment, alleged on appeal that his case was governed by the Sixth Amendment's guarantee to trial by jury ${ }^{16}$ as incorporated by the Due Process Clause of the Fourteenth Amendment. ${ }^{17}$

In considering Duncan's incorporation argument, the Court considered whether the right to trial by jury was among the

the Court, such rules automatically take effect unless blocked by Congress. See 28 U.S.C. $\$ 2072-2074$ (1994).

"The Judicial Conference rejected the proposal by voice vote at its September 1996 meeting, but ordered a subcommittee to further study the issue. See U.S. Judicial Group Rejects Twelve-Member Jury Proposal, REUTERS N. AM. WIRE, Sept. 17, 1996, available in 1996 WL 11798812.

12 See FED. R. CRIM. P. 23(b).

1s See infra Part III. This Comment presents an updated survey of the status of state criminal-jury sizes in the United States.

14391 U.S. 145 (1968).

15 See LA. CONST. of 1921, art. VII, $\$ 41$.

${ }^{16}$ For the relevant text of the Sixth Amendment, see supra note 5.

${ }^{17}$ The Fourteenth Amendment reads, in pertinent part:

All persons born or naturalized in the United States, and subject to the jurisdiction thereof, are citizens of the United States and of the State wherein they reside. No State shall make or enforce any law which shall abridge the privileges or immunities of citizens of the United States; nor shall any State deprive any person of life, liberty, or property, without due process of law....

U.S. CONST, amend. XIV, $§ 1$. 
"fundamental principles of liberty and justice which lie at the base of all our civil and political institutions." ${ }^{, 18}$ Ruling that trial by jury in criminal cases was a fundamental principle of American jurisprudence, the Court held that "the Fourteenth Amendment guarantees a right of jury trial in all criminal cases which-were they to be tried in a federal court-would come within the Sixth Amendment's guarantee. ${ }^{19}$ Holding that Duncan's misdemeanor was such a case, the Court ruled that the state court's decision to deny Duncan's demand for a jury trial violated the Constitution. ${ }^{20}$

In explaining its decision, the Court enunciated the first of the two stated purposes of the modern-day criminal jury:
A right to jury trial is granted to criminal defendants in order to prevent oppression by the Government.... Providing an accused with the right to be tried by a jury of his peers gave him an inestimable safeguard against the corrupt or overzealous prosecutor and against the compliant, biased, or eccentric judge. If the defendant preferred the common-sense judgment of a jury ... he was to have it.... The deep commitment of the Nation to the right of jury trial in serious criminal cases... qualifies for protection under the Due Process Clause of the Fourteenth Amendment, and must therefore be respected by the States. ${ }^{21}$

Although the Duncan Court did not explicitly define "serious criminal cases" and declined to draw a bright-line distinction between petty offenses and serious crimes, ${ }^{22}$ the Court held that because simple

${ }^{18}$ Herbert v. Louisiana, 272 U.S. 312, 316 (1926), quoted in Duncan, 391 U.S. at 148.

19 Duncan, 391 U.S. at 149.

${ }^{20}$ See id. at 150 . The second frequently cited "purpose of the jury" is enunciated by Justice White's majority opinion in Williams. See infra note 36 and text accompanying notes $35-36$.

21 Duncan, 391 U.S. at 155-56.

${ }_{22}$ Although the Court cited the definition of "petty offense" used in the federal courts ("those punishable by no more than six months in prison and a $\$ 500$ fine"), and the common practice of the Framers in late-eighteenth-century America, where nonjury trials were almost always restricted to crimes punishable by a prison term of six months or less, the Court refused to pinpoint a six-month prison term as the upper limit of a petty offense. See id. at 161-62.

The Court, however, cited a number of cases establishing the differences between petty and nonpetty offenses. Among these were Cheff $v$. Schnackenberg, 384 U.S. 373, 379-80 (1966) (holding that crimes carrying jail terms of less than six months in duration do not require a jury trial if they meet the other qualifications for petty offenses), and District of Columbia v. Clawans, 300 U.S. 617, 625 (1937) (establishing the penalty established for a general crime, as opposed to the penalty actually imposed for the specific occurrence, as the significant factor in determining an act's status as a "serious crime," and potentially determining when the Sixth Amendment mandate to trial by jury is applicable). 
battery was punishable in Louisiana by as much as a two-year prison term, it was a nonpetty offense requiring a jury trial. ${ }^{23}$

When Duncan incorporated the right of trial by jury in criminal cases into the Fourteenth Amendment, the Court implicitly assumed that these state criminal juries, like their federal counterparts, would have twelve-member panels. ${ }^{24}$ Two years later, however, the Court in Williams would decide differently.

In Williams, the petitioner was charged with robbery and moved for trial before a twelve-person jury instead of the six-person jury permitted by a Florida statute in all noncapital criminal cases. ${ }^{25}$ The trial court denied Williams's motion. He was tried before a jury of six, convicted, and sentenced to life imprisonment. Williams challenged the conviction on Sixth Amendment grounds, claiming that his constitutional right to trial by jury entitled him to a twelveperson jury instead of the six-member panel provided by Florida law. ${ }^{26}$

By a five-to-three majority, ${ }^{27}$ the Court in Williams held that although earlier cases assumed that the Sixth Amendment right to trial by jury required a jury of twelve, ${ }^{28}$ "the 12 -man panel is . . . not a

The Court subsequently determined that an offense is "non-petty," even if the maximum authorized prison sentence is six months or less, if additional statutory penalties are "so severe that they clearly reflect a legislative determination that the offense in question is a 'serious' one." Blanton v. City of N. Las Vegas, 489 U.S. 538, 543 (1989).

${ }^{23}$ See Duncan, 391 U.S. at 161-62.

24 See 1 The CONSTITUTIONAL LAw DictionaRY 256 (Ralph C. Chandler et al. eds., 1985) [hereinafter DICTIONARY] ("Duncan v. Louisiana ... presumed state juries would have 12 jurors ....").

${ }^{25}$ See Williams, 399 U.S. 79, 79-80 (1970). The statute read, in pertinent part: "Twelve men shall constitute a jury to try all capital cases, and six men shall constitute a jury to try all other criminal cases." Id. at 80 n.3 (quoting FLA. STAT. ANN. $§ 913.10$ (1) (West 1967)).

${ }^{26}$ See id. at 79-80, 86 .

${ }^{27}$ Justice Blackmun did not take part in the decision.

${ }^{28}$ See Williams, 399 U.S. at 90-92 \& nn.26-31. The Court discussed the following cases: Patton $v$. United States, 281 U.S. 276, 288 (1930) (stating that the Sixth Amendment jury was characterized by three essential features: "(1) that the jury should consist of twelve men, neither more nor less; (2) that the trial should be in the presence and under the superintendence of a judge... and (3) that the verdict should be unanimous"); Rassmussen v. United States, 197 U.S. 516, 517 (1905) (stating that the jury to which the Sixth Amendment referred was intended to be a jury of 12); Maxwell v. Dow, 176 U.S. 581, 586 (1900) (concluding that there was "no doubt" that the Sixth Amendment was intended to require a jury of 12 members); Thompson $v$. Utah, 170 U.S. 343, 349 (1898) (noting that the jury to which the Sixth Amendment referred was intended to be a jury "constituted, as it was at common law, of twelve persons, neither more nor less"). 
necessary ingredient of "trial by jury.",29 The Court found that Williams's trial before a six-person jury was constitutional. Writing for the majority, Justice White proffered two justifications for the Court's conclusion.

First, although Justice White conceded that "[i]t may well be that the usual expectation [of the Framers] was that the jury would consist of $12,{ }^{, 30}$ he noted that there was no historical evidence suggesting that the Framers intended the twelve-person jury to be an "indispensable component of the Sixth Amendment." ${ }^{31}$ As such, Justice White concluded that "[n]othing in this history suggests, then, that we do violence to the letter of the Constitution by turning to other than purely historical considerations to determine which features of the jury system, as it existed at common law, were preserved in the Constitution." ${ }^{32}$

With the "yoke of history" thus removed, Justice White noted that the real inquiry should examine the functions of the twelveperson jury in light of the primary purposes of the jury trial. ${ }^{34}$ Discussing the purpose of the modern-day jury, ${ }^{35}$ Justice White determined that:

[T] he essential feature of a jury obviously lies in the interposition between the accused and his accuser of the commonsense judgment of a group of laymen, and in the community participation and shared responsibility that results from that group's determination of guilt or innocence. The performance of this role is not a function of the particular number of the body that makes up the jury. To be sure, the number should probably be large enough to promote group deliberation, free from outside attempts at intimidation, and to provide a fair possibility for obtaining a representative cross-section of the community. ${ }^{36}$

Concluding that (1) a six-person jury would not suffer increased susceptibility to intimidation and would be as effective at deliberation, (2) the differences between six- and twelve-person juries in providing a fair cross-section of the community would be negligible, and (3) the

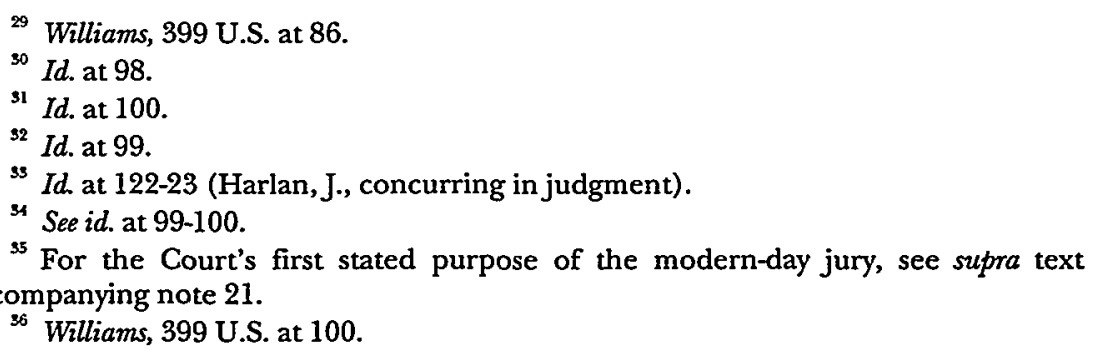


jury's reliability as a factfinder would not decrease with its reduction in size, Justice White dismantled what previously was construed as one of the most secure and axiomatic protections of American law. ${ }^{37}$

Concurring in the result in Williams, Justice Harlan accused the majority of diluting "the settled meaning of the federal right to a trial by jury. ${ }^{38}$ Although Justice Harlan sided with the majority in holding that the "right" to a twelve-person jury did not extend to state criminal trials, he claimed this was because Duncan was wrongly decided. ${ }^{39}$ Justice Harlan adamantly believed that the Sixth Amendment guaranteed a right to a trial by a jury of twelve; ${ }^{40}$ he just did not believe that the Sixth Amendment applied to the states through incorporation. ${ }^{41}$

In the years following the Court's dismantling of the twelveperson jury requirement, state legislatures tested the constitutional validity of other Sixth and Seventh Amendment rights to trial by jury. ${ }^{42}$ After Williams and Apodaca v. Oregon stripped the Sixth

${ }^{37}$ See id. at 100-02 (discussing three principal effects of a six-person jury); see also DICTIONARY, supra note 24, at 255-56 (discussing the significance of Williams and jury size and noting Justice White's discussion of three principal effects of a six-person jury).

${ }^{3}$ Williams, 399 U.S. at 138 (Harlan, J., concurring in judgment).

${ }^{39}$ See id. at 118 (Harlan, J., concurring in judgment).

${ }^{10}$ Justice Harlan strongly criticized the majority's conclusion that the twelveperson jury was a "historical accident," noting that this accident "has recurred without interruption since the 14th century," id. at 125, and protesting that the Court "stripp[ed] off the livery of history from the jury trial," id. at 122. Justice Harlan also criticized the majority for ignoring the weight of stare decisis, stating that " $[t]$ he circumvention of history is compounded by the cavalier disregard of numerous pronouncements of this Court that reflect the understanding of the jury as one of 12 members." Id. at 126. For discussion of prior Supreme Court cases iterating the Sixth Amendment's contemplation of a twelve-person jury, see supra note 28 and accompanying text.

${ }^{11}$ See Williams, 399 U.S. at 117-18 (Harlan, J., concurring in judgment) (stating that the incorporation doctrine did not fit well with our federal structure and that Duncan was wrongly decided).

${ }^{12}$ Some of the Williams-progeny cases addressed the question of jury unanimity, a subject largely beyond the scope of this Comment. The Court first addressed the question of whether jury unanimity was implicit in the text of the Sixth Amendment in Apodaca v. Oregon, 406 U.S. 404 (1972).

In Apodaca, the petitioners challenged the validity of their nonunanimous convictions on various felony charges, arguing that the Sixth Amendment did not contemplate nonunanimous juries. See id. at 406 . The Court, in a plurality opinion written by Justice White, ruled that unanimity, another element historically regarded to be required by the Sixth Amendment, was not constitutionally mandated. See id. at 411 (plurality opinion) ( $[\mathrm{W}] \mathrm{e}$ perceive no difference between juries required to act unanimously and those permitted to convict or acquit by votes of 10 to two or 11 to one."). Justice Powell, concurring in a companion case, found that Duncan was 
Amendment of its size and unanimity requirements in state criminal cases, there remained no principled stopping points for the Court to prevent the further erosion of the size of the state criminal jury. ${ }^{43}$

One year after Apodaca, in Colgrove v. Battin, the Court extended the principle announced in Williams to civil juries. ${ }^{44}$ In Colgrove, the Court held that the Seventh Amendment's trial-by-jury guarantee was satisfied by a six-person jury. ${ }^{45}$ In reaching this decision, the Colgrove Court hearkened back to the Williams decision in restating that the reliability of the jury as factfinder was not a function of its size. The Court thus decided that departing from the previous twelve-member standard in federal civil cases would not do violence to any

wrongly decided, and adopted Justice Harlan's partial-incorporation position, ruling that although the Sixth Amendment right to trial by jury presupposed a unanimous verdict in federal trials, states could deviate from the unanimity requirement because all Sixth Amendment guarantees were not extended to the states through due process requirements. See Johnson v. Louisiana, 406 U.S. 356, 369 (1972) (Powell, J., concurring) ("I do not think that all of the elements of jury trial within the meaning of the Sixth Amendment are necessarily embodied in or incorporated into the Due Process Clause of the Fourteenth Amendment."). For further discussion, see DiCTIONARY, supra note 24, at 257-58, and GERALD GUNTHER, CONSTITUTIONAL LAW 430-31 (12th ed. 1991).

The Apodaca plurality followed the reasoning of the Williams majority in deciding that, like that of the twelve-person jury, the history of the unanimity requirement was "not of constitutional stature" when considered in the light of the function it was intended to perform. Apodaca, 406 U.S. at 406 (plurality opinion). Citing the language in Duncan that established the function of the jury in modern society, see Duncan v. Louisiana, 391 U.S. 145, 155-56 (1968), the Apodaca plurality found that a constitutional requirement of unanimity in criminal jury verdicts would "not materially contribute" to the jury's designated function of "interpos[ing] between the accused and his accuser ... the commonsense judgment of a group of laymen." Apodaca, 406 U.S. at 410 (plurality opinion) (citing Williams, 399 U.S. at 100).

The immediate problem raised by the plurality decision in Apodaca was just how nonunanimous a nonunanimous verdict in a criminal trial could get before it began to encroach on the "beyond a reasonable doubt" standard required for criminal conviction. Anticipating this issue, Justice Blackmun, in his concurrence in Johnson, explicitly noted that his decision did not imply that he regarded "a State's split-verdict system as a wise one." Johnson, 406 U.S. at 366 (Blackmun, J., concurring).

Nevertheless, Apodaca established the constitutional sufficiency of nine-to-three convictions in state criminal trials. The sufficiency of closer margins and nonunanimous decisions of juries smaller than 12 but larger than six remains an open question. See DiCTIONARY, supra note 24, at 258 ("Apodaca and Williams opened doors relative to jury decision and size long thought... locked shut.").

${ }^{43}$ See, e.g., Elizabeth Decker Tanke \& Tony J. Tanke, Getting off a Slippery Slope: Social Science in the Judicial Process, 34 AM. PSYCHOL. 1130, 1131 (1979) ("[T] he Court would be confronted with successively smaller 'juries' until it was forced to declare a minimum size or to permit jury trial to pass into oblivion.... The Court's own [functional] test left it with no reasonable avenue of escape.").

14 Colgrove v. Battin, 413 U.S. 149 (1973).

${ }^{45}$ See id. at 159-60. 
"substantive aspect of the right of trial by jury."

The Colgrove Court also cited four studies as "convincing empirical evidence of the correctness of the Williams conclusion that there is 'no discernible difference between the results reached by the two different-sized juries." ${ }^{47}$ As a result, the Court concluded that "nothing ... persuades us to depart from the conclusion reached in Williams.... [W] hile we express no view as to whether any number less than six would suffice, we conclude that a jury of six satisfies the Seventh Amendment's guarantee of trial by jury in civil cases."

Many states have since accepted the Court's invitation to depart from their twelve-person jury standards and unanimity requirements in civil and criminal cases. ${ }^{49}$ This widespread departure from such requirements lends special weight to Justice Marshall's warnings in his Colgrove dissent that the Court had, through its decisions in Williams, Apodaca, and Colgrove, eradicated any principled way to "get off the "slippery slope" before . . . reach [ing] the bottom." ",50

The Court faced this reality with zealous unanimity in Ballew $v$. Georgia, a case where a criminal defendant had been tried and convicted by a five-person jury pursuant to Georgia law. ${ }^{51}$ In Ballew, the Court ruled that "the purpose and functioning of the jury in a criminal trial is seriously impaired . . . by a reduction in size to below six members" ${ }^{32}$ and "creat[es] a substantial threat to Sixth and Fourteenth Amendment guarantees."53 The Georgia Court of Appeals had cited Williams previously in rejecting Ballew's argument that his trial before a five-person panel violated his Sixth Amendment right to trial by jury. ${ }^{54}$

${ }^{46}$ Id. at 157.

${ }^{17}$ Id. at 158 (quoting Williams, 399 U.S. at 101). For a complete analysis of how proper interpretation of this "convincing empirical evidence" would have led the Court to a different conclusion, see infra Part IV.

${ }^{48}$ Colgrove, 413 U.S. at $159-60$ (footnote omitted).

49 See DiCTIONARY, supra note 24, at 258 ("Many states have accepted the Court's invitation to alter their policies [regarding jury decision and size] accordingly."); see also infra Part III (outlining the current status of state criminal-jury requirements).

${ }^{\text {so }}$ Colgrove, 413 U.S. at 181 n.9 (Marshall, J., dissenting) (quoting Williams, 399 U.S. at 91 n.28).

${ }^{51} 435$ U.S. 223 (1978).

52 Id. at 239.

3s Id. at 243 .

${ }^{54}$ See id. at 228 (discussing the decision of the Georgia Court of Appeals). Absent a holding by the Supreme Court that a five-person jury was constitutionally inadequate, the Georgia Court of Appeals considered itself bound by state-court precedent which, for reasons of administrative convenience and judicial economy, had 
The unanimous Ballew Court, including all five members of the Williams majority who, eight years earlier, had voted to allow states to depart from the twelve-person jury standard, was forced to draw an arbitrary line. ${ }^{55}$ Seeking a logical underpinning for its decision, the Court examined the growing body of social-science research comparing six- and twelve-person juries undertaken in response to the Williams decision. The Court, however, misapplied the findings of this research to support its desired conclusion that effective functioning of a criminal jury is constitutionally impaired when it falls below six members. ${ }^{56}$

Guided by misapplied research findings, the Ballew Court set the minimum boundary marker for the state criminal jury at six members. As Part IV of this Comment will demonstrate, however, a proper interpretation of the studies upon which the Ballew majority relied could have produced only one result: the reversal of Williams and the reinstatement of the twelve-person jury requirement. ${ }^{57}$

allowed the practice. The Georgia prosecutor in Ballew seized upon language in Williams that stated, "We have no occasion in this case to determine what minimum number can still constitute a "jury," but we do not doubt that six is above that minimum" and argued that "[i]f six is above that minimum, five cannot be below the minimum [because] [t] here is no number in between."' Id. at 230-31 n.9 (plurality opinion) (quoting Brief for Respondent at 4).

${ }^{55}$ See id. at 239 (plurality opinion) ("We readily admit that we do not pretend to discern a clear line ....").

${ }^{56}$ See id. (plurality opinion) ("Because of the fundamental importance of the jury trial to the American system of criminal justice, any further reduction that promotes inaccurate and possibly biased decisionmaking, that causes untoward differences in verdicts, and that prevents juries from truly representing their communities, attains constitutional significance."). For a complete discussion of the Court's misapplication of this research, see infra Part IV.D.

${ }^{57}$ Part IV will show how the Court in Ballew finally interpreted the body of socialscience research correctly, only to misapply its conclusions. See discussion infra Part IV. Nearly all the studies cited by the Ballew Court examined the.differences between six-and twelve-person juries and concluded that twelve-person juries were significantly preferable to juries composed of six. The Ballew Court, however, manipulated these findings to support their necessary, but entirely different, conclusion that a five-person jury unconstitutionally impaired jury function, while the six-person jury approved in Williams did not.

With the minimum state criminal jury size set at six by Ballew, and the constitutionality of nonunanimous verdicts confirmed by Apodaca, it took less than a year for the Court to grant certiorari in the final case in the Williams line, Burch $v$. Louisiana, 441 U.S. 130 (1979). Predictably, Burch involved provisions of a state constitution and a state code of criminal procedure that allowed misdemeanor convictions by nonunanimous juries of six. See LA. CONST. of 1921 art. VII, $\S 41$ ("A case in which the punishment may be confinement at hard labor or confinement without hard labor for more than six months shall be tried before a jury of six persons, five of whom must concur to render a verdict."); LA. CODE CRIM. PROC. ANN. art. 
Although the twelve-person jury and the unanimous verdict requirements in criminal trials have been retained in federal courts, ${ }^{58}$ Williams and its progeny have seriously eroded state criminal juries, which hear the great majority of criminal cases. At the state level, the former presumption of a unanimous verdict by a twelve-person jury has given way to a constitutional right to a criminal trial before something between a six-person unanimous jury and a twelve-person jury permitted to reach a nine-to-three verdict. The constitutionality of closer margins in twelve-person jury trials, and of possible intermediate jury size and unanimity combinations, remains unresolved. $^{59}$

Williams and its progeny have left state criminal-jury requirements in utter disarray, and, in many cases, of questionable constitutionality. More importantly, defendants' due process and liberty interests are presently safeguarded by juries that do not function according to the Framers' intent as interpreted in Duncan and Williams. ${ }^{60}$ Just how severely these eroded criminal juries are malfunctioning, and how greatly this malfunction jeopardizes the integrity of the criminal-jury process, will be addressed in Part IV of this Comment.

779(A) (West Supp. 1979) ("A defendant charged with a misdemeanor ... shall be tried by a jury of six jurors, five of whom must concur to render a verdict.").

The Burch Court disagreed with the Louisiana Supreme Court's conclusion that conviction by a five-sixths majority of a six-person jury did not offend a defendant's Sixth Amendment rights. See Burch, 441 U.S. at 133 (citing State v. Wrestle, Inc., 360 So. $2 \mathrm{~d} 831,838$ (La. 1978)). The Court ruled that "conviction by a nonunanimous sixmember jury in a state criminal trial for a nonpetty offense deprives an accused of his constitutional right to trial by jury." Id. at 134. Recognizing Burch as the culmination of its decisions on jury size and unanimity, the Court concluded:

[W] do not pretend the ability to discern a priori a bright line below which the number of jurors participating in the trial or in the verdict would not permit the jury to function in the manner required by our prior cases. But having already departed from the strictly historical requirements of jury trial, it is inevitable that lines must be drawn somewhere if the substance of the jury trial right is to be preserved.

Id. at 137 (citations omitted). As a result, the Burch Court unanimously ruled that if a state had reduced the size of its criminal jury to the constitutional minimum of six, only a unanimous verdict could pass constitutional muster. See id. at 139.

${ }^{33}$ See FED. R. CRIM. P. 23(b). See infra note 144 for the text of the rule.

59 See DICTIONARY, supra note 24, at 258 (noting that Apodaca and Williams reopened the possibility of intermediate size and unanimity values).

${ }^{50}$ See supra notes 28-31, 40 and accompanying text (discussing the Justices' competing interpretations of how the Framers envisioned the jury). 


\section{THE ORIGINS OF THE TWELVE-PERSON JURY}

\section{A. Leading Theories}

The precise wellspring of the twelve-person jury is somewhat uncertain. Although the issue has been studied and debated for more than a century, there is still no agreement about it. ${ }^{61}$ Scholars have traced the origins to sources as diverse as ancient Greece, ${ }^{62}$ the Roman Conquest, ${ }^{63}$ the Biblical importance of the number twelve, ${ }^{64}$ ancient reliance on court astrologers, ${ }^{65}$ the Anglo-Saxon era in England, ${ }^{66}$ the Norman Conquest, ${ }^{67}$ the Assize of Clarendon, ${ }^{68}$ and the Magna Carta. ${ }^{69}$ Some explanations are more convincing than others, but if one heeds the words of Sir Edmund Burke-that modern juries have not "jumped, like Minerva, out of the head of Jove in complete armor, ${ }^{70}-$ one finds more than sufficient evidence to conclude that the evolution of the modern jury as a body of twelve-persons was far

${ }^{61}$ See William Forsyth, History of Trial BY JuRY 2 (2d ed., Lenox Hill Publ'g \& Distrib. Co. 1971) (1878) ("Few subjects have exercised the ingenuity and baffled the research of the historian more than the origin of the jury."); Larry T. Bates, Trial by Jury After Williams v. Florida, 10 HAMLINE L. REV. 53, 53 (1987) ("The origin of the Anglo-American jury is a much disputed question.").

${ }_{62}$ See LLOYD E. MOORE, THE JURY 1 (2d ed. 1988) (describing the trial of Orestes on the charge of matricide); see also infra notes 71-75 and accompanying text.

${ }^{63}$ See MOORE, supra note 62, at 3 (discussing the way in which the Romans brought their form of the jury to England); see also infra notes 71-75 and accompanying text.

${ }^{64}$ See PATRICK DEVLIN, TRIAL BY JURY 8 (1956) (listing religious explanations for a jury of twelve); see also infra note 81 (citing authorities that trace the number 12 to Scripture).

${ }^{65}$ See John A. Matthews, The Jury-Old Wine in New Bottles, 39 FLA. B.J. 94, 94-97 (1965) (looking for modern substance in the idea that one juror was chosen for each of the 12 signs of the Zodiac).

${ }^{66}$ See 1 Frederick POLlock \& Frederic William Maitland, THe History of ENGLISH LAW BEFORE THE TIME OF EDWARD I, at 38-39 (2d ed. 1899) (tracing the origins of the jury to Anglo-Saxon oath-swearers).

${ }_{67}$ See CHARLES HOMER HASKInS, NORMAN INSTITUTIONS 196-238 (1918) (tracing the roots of the English jury from the Norman Conquest); see also infra notes 76-80 and accompanying text.

${ }^{6}$ See THEOdore F.T. PluckNeTt, A CONCISE History OF THE COMMON LAW 97110 (1929) (discussing the regular procedures established by the Assize of Clarendon); see also infra notes 86-89 and accompanying text.

${ }^{69}$ See, e.g., Thompson v. Utah, 170 U.S. 343, 349 (1898) (stating that the jury contemplated by the Magna Carta was a jury of 12); see also infra notes 92-107 and accompanying text.

${ }^{70}$ MOORE, supra note 62, at 14 (quoting 6 THE WORKS AND CORRESPONDENCE OF EDMUND BURKE 138 (Charles William and Sir Richard Bourke eds., London 1852)). 
from accidental.

\author{
1. The Greeks and Romans, \\ and the Influence of the Gods and Religion
}

According to ancient mythology, the first trial ever held on the Areopagus $^{71}$ was the trial of Ares, god of War, for the murder of Halirrhothius, the son of Poseidon, god of the Sea. That earliest of recorded jury cases was tried before a panel of twelve gods. The panel deadlocked at six to six, resulting in Ares's acquittal. ${ }^{72}$ The earliest known jury trial of a "mortal" also involved a jury of twelve. This trial was the subject of Aeschylus's play, The Eumenides, first presented in 458 B.C. ${ }^{73}$ Most scholars concede, however, that any direct line of influence between the Greek and Roman legal systems and the development of the English jury was "lost in the night of time." ${ }^{74}$ Nevertheless, the residual-influence theory has not been dispelled, and many scholars believe that the recorded history of the Greeks and Romans played an influential role in the development of the English jury. ${ }^{75}$

\title{
2. The Jury During the Norman Invasion of England
}

Many scholars have traced the origins of the English jury to the bifurcated nature of Charlemagne's Frankish inquisito, brought to the

"The Areopagus was the hill where the supreme tribunal of Athens convened.

72 See THE NEw CENTURY Classical HaNdBOOK 142 (Catherine B. Avery ed., 1962) (noting that Ares was acquitted because "he was protecting his daughter's honor").

${ }^{73}$ See Aeschylus, OResteia: Agamemnon, THE Libation Bearers, The Eumenides 135, 161 (David Grene \& Richmond Lattimore eds., Richmond Lattimore trans., Univ. of Chicago Press 1953) (n.d.) (explaining how Pallas Athena, patron goddess of the Trojans, broke the six-to-six tie in the jury of 12 Athenian citizens in Orestes's trial for the murder of his mother, Clytemnestra, who had earlier murdered his father Agamemnon); see also MOORE, supra note 62, at 1 (recounting the trial of Orestes).

${ }^{74}$ Richard S. Arnold, Trial by Jury: The Constitutional Right to a Jury of Twelve in Civil Trials, 22 HOFSTRA L. REV. 1, 6 n.19 (1993) (quoting FORSYTH, supra note61, at 2).

${ }^{75}$ See JEROME Frank, CourTS ON TRIAL 108 (1949) (stating that the "germ" of the modern jury may have its roots in fifth-century Roman practice); MAXIMUS A. LESSER, THE HiSTORICAL DEVElopMENT OF THE JURY SYSTEM 171 (New York, Lawyer's Cooperative 1894) (stating that "an institution resembling the modern jury in various respects must have existed in England-brought thither by the Romans, and originating among the Greeks-at the earliest civilized period"); MOORE, supra note 62 , at 4 (suggesting that the idea of the jury was passed down through time from the Egyptians to the Greeks to the Romans); POLLOCK \& MAITLAND, supra note 66, at 14142 (suggesting that the Frankish inquisito, more definitively accepted as an ancestor of the English jury, was influenced by the Roman system). 
English mainland by the Franks during the Battle of Hastings in $1066 .^{76}$ The inquisito had an accusatory component-perhaps the precursor of the modern grand jury-followed by a determination of proof by interrogation, suggestive of the modern petit jury. ${ }^{77}$ Although this theory fails to account for the already developing system of juries in England during the Anglo-Saxon period preceding William's invasion, ${ }^{78}$ scholars note that the Frankish system had "considerable influence on the courts of William the Conqueror" in the centuries following the invasion. ${ }^{79}$ According to these scholars, no system of laws in eleventh-century England remotely compared to that which William brought across the Channel to England in $1066 .^{80}$

Many of the earliest definitive references to a jury of twelve are linked to church-related matters, where the Biblical significance of

${ }^{76}$ See HEINRICH BRUNNER, DIE ENTSTEHUNG DER SCHWURGERICHTE [THE ORIGIN OF JURIES] 92, 118 (Berlin, Weidmannsche Buchhandlung 1872) (demonstrating through a comparison of language contained in documents from the Frankish and Anglo-Norman eras that the Frankish inquisito and the English jury probably had a common origin); WILLIAM HOLDSWORTH, A HISTORY OF ENGLISH LAW 312 (7th ed. 1956) (stating that the inquisito is "the root from which the English jury springs"); POLLOCK \& MAITLAND, supra note 66 , at 141-42 (calling the jury the "palladium of our liberties" and ascribing its origin to the Frankish rather than the English); Arnold, supra note 74, at 6-7 ("The best guess now [about the origin of the jury] seems to be that William the Conqueror brought the jury across the Channel to England with the Frankish inquisito in 1066, and that the English jury finally took root at that time, eventually developing into its modern form toward the end of the fourteenth century.").

7 See MOORE, supra note 62, at 14 (discussing the inquisito). The "petit jury" is the jury for the trial of a civil or criminal action. It was given this name to distinguish it from the grand jury. See BLACK's LAW DICTIONARY 856 (6th ed. 1990).

${ }^{78}$ See MOORE, supra note 62 , at $24-25$ (discussing various statutes providing for juries which were in force in England during the period before William's invasion). Moore illustrates that a twelve-person jury might have been developing in Anglo-Saxon England prior to, and exclusive of, the Norman system, discussing several statutes of the Saxon Kings, including statutes of King Aethelred I (865-871) ("Twelve laymen shall administer the law ...."); King Alfred the Great (871-899) ("If a royal thane be accused of homicide he shall purge himself with twelve royal thanes. Any other man shall purge himself with eleven of his own rank and one royal thane."); King Eadgar the Peaceful (959-975) ("[T]welve witnesses ... should be appointed to swear to make true depositions."); and King Aethelred II, the Unready (978-1016) (declaring that "a moot would be held in every wapentake," whereby the 12 oldest thegns take an oath to serve justice). $I d$. at 25-26.

${ }^{79}$ Id. at 17.

${ }^{\text {so }}$ See id. at 18, 33-34, 34 ("Norman law... made a deep impression on English society."); Arnold, supra note 74, at 6 ("William the Conqueror brought the jury across the Channel to England ...." ). 
the number twelve was clearly an influence. ${ }^{81}$ An inquest ordered to determine the proper extent of the lands held by the Church at Ely, alternatively dated between 1083 and 1086, is thought to be the first historically verifiable use of such a jury in an English court. ${ }^{82}$

Henry II, who reigned in England from 1154 to 1189, introduced the most expansive legal changes in English history. ${ }^{83}$ One of Henry II's most significant contributions was the Constitution of Clarendon, enacted in 1164 to address problems of class intimidation. This Constitution provided that "[t]he sheriff shall cause 12 legal men of the neighborhood ... to take an oath in the presence of the bishop that they will declare the truth." ${ }^{84}$ These sworn juries were also expected to render verdicts of guilt or innocence, eclipsing the former tasks of accusatory courts, and providing the first real operational similarity to the modern jury. ${ }^{85}$

The creation of the Grand Assize of Clarendon, a court designed by Henry II, however, is widely recognized as the most significant event in the initial establishment of the English jury. ${ }^{86}$ The Assize

81 See, e.g., 1 EDWARD COKE, THE FIRST PART OF THE INSTITUTES OF THE LAWES OF ENGLAND 155 (photo. reprint 1979) (1628) ("And that number of twelve is much respected in holy Writ, as 12 apostles, 12 stones, 12 tribes, etc."); DEVLIN, supra note 64 , at 8 (noting the importance given to the number 12 in selecting political and judicial bodies and suggesting that the number 12 had Biblical significance); JOHN PROFFATT, TRIAL BY JURY 112 n.4 (San Francisco, Sumner Whitney \& Co. 1877) (“[T] his number is no less esteemed by our own law than by holy writ. If the twelve apostles on their twelve thrones must try us in our eternal state, good reason hath the law to appoint the number twelve to try us in our temporal. The tribes of Israel were twelve, the patriarchs were twelve, and Solomon's officers were twelve."); Arnold, supra note 74, at 12 (noting that as far back as the year 725, Morgan of Gla-Morgan, an ancient King of Wales, referred to trial by jury as Apostolic Law when he stated, "For... as Christ and his twelve apostles were finally to judge the world, so human tribunals should be composed of the king and twelve wise men").

${ }^{82}$ See MOORE, supra note 62 , at 33 . This inquest stemmed from a dispute between one of the King's sheriffs and the Bishop of Rochester, both of whom claimed the same land. With the Bishop of Bayeaux presiding, the jurors, fearing the King, decided in his favor. The Bishop instead ordered the jury to choose 12 from their number to take an oath and confirm the verdict. See id. The fact that an English bishop ordered a jury of 12 to be seated lends support to the theories suggesting a Biblical origin for the twelve-person requirement.

${ }^{8 s}$ See id. at 34 (noting that Henry II "introduc[ed] more far reaching legal changes than any other Monarch that ever held that throne").

${ }^{81}$ Id. at 35 (citation omitted).

${ }^{85}$ See id. (discussing the provisions of the Constitution of Clarendon).

${ }^{86}$ See id. ("Of all the legislation of Henry II, the Grand Assize ... proved to be the most far reaching in terms of establishing the jury."). See generally JOHN BEAMES, A TRANSLATION OF GLANVILLE (London, A.J. Valpy 1812) (describing the structure and function of the Grand Assize). 
gave an individual whose tenant rights to property were challenged an alternative to a duel-namely, to place himself before the Grand Assize and have his dispute settled by an inquest of four knights and twelve neighbors. ${ }^{87}$ If the claimant chose the Assize, a writ would issue which requested the king to "[s] ummon ... four lawful Knights of the Vicinage ... to elect on their oaths, twelve lawful Knights of that Vicinage, who better know the truth, to return, on their oaths, whether [the tenant] or [the claimant] ... have the greater right in that land ...." ${ }^{88}$ The king's knights appeared and chose twelve jurors, who were summoned to court to render a verdict. The tenant and the claimant had the right to attend the election of the jury and to challenge the knights' selections for good cause. At the time of the Assize of Clarendon, the requirement of twelve was firmly established, because if fewer than twelve of the elected jurors had sufficient knowledge of the facts, additional jurors were elected until a jury of twelve was in place. ${ }^{89}$

There were various other "neighborhood inquests" during the reign of Henry II, including those in the Assize of Northampton in 1176, the Assize of Darrein in 1181, and the Assize of the Forest in $1184 .^{90}$ In all of the above, the jury was assembled according to the issuance of a royal writ summoning "twelve free and lawful men."

\section{The Jury at the Time of the Magna Carta}

The Magna Carta, issued by King John at Runnymede on June 15, 1215, is regarded as "the foundation of English constitutional liberty." ${ }^{92}$ The first constitutional right to a jury trial was among its credits. $^{93}$ Most modern authorities do not place the granting of this right in the seemingly obvious article $39,{ }^{94}$ but rather in the more

${ }^{87}$ See MOORE, supra note 62 , at 36.

${ }^{88} I d$. at 36-37. "Vicinage" was a common-law geographical term similar to a "district."

${ }^{89}$ See id. at 37.

${ }^{90}$ See id. at 38.

${ }^{91}$ Id.

92 BLACK's LAW DictionARY 951-52 (6th ed. 1990).

${ }^{93}$ See MOORE, supra note 62, at 47 ("[The Magna Carta] has commonly been credited with guaranteeing trial by jury."); Arnold, supra note 74, at 13 ("[T]he constitutional right to a jury trial was guaranteed by the Magna Carta ....").

${ }^{94}$ Article 39 of the Magna Carta reads: "No freeman shall be seized, or imprisoned, or dispossessed, or outlawed, or banished, or any way destroyed; nor will we condemn him, nor will we commit him to prison, excepting by the legal judgment of 
subtle language of article $36 .^{95}$ Lloyd Moore has noted that article 39 's reference to "peers" did not necessarily imply "jurors," but that article 36's reference to "inquisition," read in its historical context, can be interpreted as "jury." Implementation of trial by jury after the Magna Carta was issued, however, was slow in coming, largely due to opposition from the Church. ${ }^{97}$ The decision in 1215 by Pope Innocent III forbidding members of the clergy from participating in "ordeals" of fire and water, however, led to the proffering of a writ by Henry III in 1219 that established trial by jury for defendants who formerly would have been subject to such ordeals. ${ }^{98}$

In 1166, the Assize of Clarendon required that certain felonies be presented to a jury of twelve individuals chosen from the residents of the county and filled by four knights from neighboring villages. In 1176, the Assize of Northampton added a second jury of twelve to the indictment process. Thus, after the Assize of Northampton, felony cases were routinely heard by two juries of twelve. ${ }^{99}$

After 1215, presentment juries, rather than ordeals, determined guilt or innocence. ${ }^{100}$ The use of presentment juries was formalized

his peers, or by the laws of the land." The Great Charter of King John (Richard Thomson trans.), reprinted in RAY STRINGHAM, MAGNA CARTA 234 (1966).

${ }^{95}$ Article 36 of the Magna Carta reads: "Nothing shall be given or taken for the future for the Writ of Inquisition of life or limb, but it shall be given without charge, and not." Id.

${ }^{96}$ The "writ of inquisition" has been read as a reference to the process of trial by jury that developed out of the Frankish inquisito. Prior to the Magna Carta, such jury trials were only available for purchase. As such, article 36 has been interpreted to be the constitutional source for free trial by jury. Cf. MOORE, supra note 62, at 48 ("A reading of the Magna Carta indicates that article 36 is the one guaranteeing jury trial.").

${ }^{97}$ The Magna Carta's provision for trials by jury triggered suspicion because it directly contravened the long-accepted principles of the Leges Henrici that the frailty of human testimony was insufficient to condemn a man to the gallows. Therefore, duels or "ordeals," such as prolonged submersion in water or encounters with fire, were thought to be more accurate ways for the accused to prove his innocence. See Bates, supra note 61, at 54-55 ("[Jury trials] went contrary to the accepted principle of law set forth in the Leges Henrici that 'mere human testimony is not enough to send a man to the gallows.'").

${ }^{3}$ See MOORE, supra note 62, at 50 (noting that Pope Innocent III's decision "was to eventually have great effect on the use of jury trial in criminal cases" (citation omitted)); Bates, supra note 61, at 54 (noting that when "the Church prohibited clergy participation in the ordeal, [it] in effect eliminated the ordeal as a method of proof"). Note again the significant interplay between the Crown and the Church in the development of the jury system-another indication that religious influence may ultimately underlie the twelve-person jury requirement.

\footnotetext{
${ }^{99}$ See Bates, supra note 61 , at 62 .

${ }^{100}$ See id.
} 
in the late thirteenth century, such that "twenty-four persons from the county were summoned and twenty-three of these were selected for service, with a majority [i.e., twelve] needed to find a 'true bill' [i.e., indictment]." If If at least twelve of the twenty-three jurors returned a true bill, the justice questioned the majority to determine their knowledge about the case and swore the twelve with the most reliable "means of knowledge" to return a verdict of guilt or innocence after deliberation. ${ }^{102}$ As a result, twelve members-a simple majority of the original indictment panel of twenty-three-were selected to deliberate the case and return a verdict.

Larry Bates and Theodore Plucknett have noted the logic of this process, since the purpose of these jury trials was "'to get information useful to the Crown from those people most likely to have it." ${ }^{103}$ The theory was that, among the twenty-four jurors who accused a defendant (from whom twenty-three were chosen), there were enough individuals possessing sufficient knowledge of the defendant's reputation to decide her guilt or innocence. After the indictment of an accused by the panel of twenty-three presentment jurors, no further information could be gained from those jurors having no additional knowledge of the defendant's reputation, so these individuals were eliminated. ${ }^{104}$ Accordingly, after the indictment, the jury panel was reduced to the twelve individuals with the best additional knowledge of the defendant's reputation.

The law mandated that a majority of the initial panel of twentythree presentment jurors both indict and convict. Thus, at least twelve of the twenty-three initial jurors were needed to indict, and a unanimous verdict of the twelve remaining impaneled jurors was needed to convict. Since even a single dissenting vote meant that the final verdict was not rendered by a majority (twelve) of the original presentment jury of twenty-three, the unanimity requirement of the modern twelve-person juries also finds a historical anchor in this process. ${ }^{105}$

As scholars have noted, the general infrastructure of the criminal jury as a twelve-member body rendering unanimous verdicts was

\footnotetext{
${ }^{101}$ Id. (citation omitted).

102 See id.

${ }^{103}$ Id. (quoting PLUCKNETT, supra note 68, at 109).

${ }^{104}$ See id. at 62-63.

${ }^{105}$ See id.
} 
clearly established by the time of Edward III in $1377 .^{106}$ This infrastructure remained largely unchanged for the next six hundred years, until the Williams Court declared the entire nine-hundred-year evolutionary process of the twelve-person jury a "historical accident." $^{\text {107 }}$

\section{B. The Framers' Intent for the American Criminal Jury}

Not surprisingly, the conceptualization of the jury that surfaced in the American colonies bore a striking resemblance to the petit jury described by English treatises, upon which the Framers heavily relied. $^{108}$ Recognizing this, the Supreme Court in Ex Parte Grossman suggested that the "language of the Constitution cannot be interpreted safely except by reference to the common law and to British institutions as they were when the instrument was framed and adopted."109 As Bates suggested, had the Williams Court followed these interpretive guidelines, they would have found the necessary evidence to leave the centuries-old tradition of the twelve-person unanimous criminal jury undisturbed. ${ }^{110}$ Instead, the Court placed considerable interpretive emphasis on the legislative history of the article III "trial by jury" clause." The majority noted that " $t]$ he "very scanty history [of this provision] in the records of the Constitutional

${ }^{106}$ See, e.g., FORSYTH, supra note 61 , at 207 (noting that the criminal jury trial was "nearly if not quite the same as at the present day"); Bates, supra note 61, at 61 (noting that by the fourteenth century in England, the structure of the criminal jury had become consistent and its use had become common).

${ }^{107}$ Williams v. Florida, 399 U.S. 78, 102 (1970).

${ }^{103}$ See Bates, supra note 61, at 64 (noting that English treatises were "major legal resources within the [c]olonies"); see also 3 MATTHEW BACON, A NEW ABRIDGMENT OF THE LAW 727 (London, A. Strahan 1807) (stating that the petit jury consisted of "twelve and can be neither more nor less"); 2 HENRY OF BRACTON, ON THE LAWS AND CUSTOMS OF ENGLAND 328-29 (George E. Woodbine ed. \& Samuel E. Thorne trans., Harv. Univ. Press 1968) (n.d) (stating that juries are composed of 12); 1 COKE, supra note 81 , at 155 (describing the jury as a twelve-person body that rendered unanimous verdicts and turning to the Bible as the original wellspring for the number 12); 2 MatThew Hale, THe History of THE Common LAw 141 (London, G.G. \& J. Robinson, Pater-Noster-Row 1794) (stating that a jury was "twelve, and no less").

${ }^{109} 267$ U.S. 87, 108-09 (1925).

${ }^{110}$ See Bates, supra note 61, at 64 .

"11 See Williams, 399 U.S. at 92-99 (providing an overview of constitutional history that casts doubt on the assumption that "if a given feature existed in a jury as common law in 1789, then it was necessarily preserved in the Constitution"). The article III clause reads, in pertinent part, "The Trial of all Crimes ... shall be by Jury; and such Trial shall be held in the State where the said Crimes shall have been committed ...." U.S. CONST. art. III, $\$ 2$, cl. 3. 
Convention' sheds little light either way on the intended correlation between article III's 'jury' and the features of the jury at common law."112 The Court acknowledged that many delegates to the Constitutional Convention were uncomfortable with article III's failure to guarantee specifically the common-law right to be tried by a "jury of the vicinage." article III made no specific provisions for trial by jury in civil cases, led to the introduction of the Sixth and Seventh Amendments in 1791. ${ }^{114}$

While it is true, as the Williams majority suggested, that few records exist of any discussion-favorable or unfavorable-of jury size in the Constitutional Convention, this is not dispositive evidence that the Framers intended to disturb the tradition of twelve-person juries. In fact, an examination of colonial legislation in the preRevolutionary and Revolutionary eras uncovers considerable evidence that the Framers simply understood "jury" to mean a unanimous body of twelve. ${ }^{115}$

${ }^{112}$ Williams, 399 U.S. at 93 (quoting Felix Frankfurter \& Thomas G. Corcoran, Petty Federal Offenses and the Constitutional Guaranty of Trial by Jury, 39 HARV. L. REV. 917, 969 (1926)).

${ }^{113} I d$.

114 See id. at 93-94 (describing the origin of the Sixth and Seventh Amendments). For a more detailed analysis of the discomfort specific to civil cases and the historical background of the Seventh Amendment, see Arnold, supra note 74, at 15-18, which explains that in order to have the Constitution ratified, the Framers had to concede to the anti-Federalists that an amendment including a specific right to a civil jury trial would be among the first acts of the first Congress. See also Stephan Landsman, The Civil Jury in America: Scenes from an Unappreciated History, 44 HASTINGS L.J. 579, 598 (1993) (suggesting that since the need for civil juries in America to counterbalance the English colonial judges appointed by the Crown had disappeared with the Revolution, many delegates trusted their elected officials to protect their rights, making juries in civil cases unnecessary); Charles W. Wolfram, The Constitutional History of the Seventh Amendment, 57 MINN. L. REV. 639, 661-62 (1973) (noting that the Framers' failure to include a civil-jury right in the text of the Constitution nearly doomed its ratification).

${ }^{115}$ Instructions in no less than six colonial charters (New Hampshire, New York, Pennsylvania, Plymouth Plantation, Virginia, and West Jersey) specified that trial by jury in criminal cases meant trial by a panel of 12 indifferent members of the community reaching a unanimous verdict. For the specific language of these charter provisions, see generally 1-4 FOUNDATIONS OF COLONIAL AMERICA (W. Kavenagh ed., 1973). For a brief summary of the provisions, see Bates, supra note 61 , at 65 . Three state constitutions ratified prior to the Federal Constitution made similar provisions for criminal trials in those states. SeeN.C. CONST. of 1776, art. IX ("[N]o freeman shall be convicted of any crime, but by the unanimous verdict of a jury of good and lawful men ...."); VT. CONST. of 1777, ch. 1, art. X ("[I]n all prosecutions for criminal offences, a man hath a right to... a speedy public trial, by an impartial jury of the country; without the unanimous consent of which jury he cannot be found 
As the Williams Court noted, the proposed text of the Sixth Amendment, as introduced by James Madison in the House of Representatives of the First Congress, stated, in pertinent part: "The trial of all crimes ... shall be by an impartial jury of freeholders of the vicinage, with the requisite of unanimity for conviction, of the right of challenge, and other accustomed requisites...""116 Although this text passed the House virtually unchanged, it created heated debate in the Senate ${ }^{117}$ and was returned to the House in the substantially different form that ultimately became the text of the Sixth Amendment. ${ }^{\text {.18 }}$

The Williams Court found this legislative history dispositive of the First Senate's interpretation that the vicinage requirement was a nonessential part of common-law trial by jury. ${ }^{119}$ By the Court's reasoning, this suggested that the conceptualization of the commonlaw jury as a whole was not perceived by the First Senate as immutable, and that since other language of the Madison draft, including the "accustomed requisites" provision, was also eliminated, these actions should be read as substantive deletions. ${ }^{120}$ The Court concluded that since Congress used explicit language to incorporate other aspects of the common-law jury system, its failure to explicitly incorporate the twelve-person requirement suggested a deliberate

guilty ...." ); VA. CONST. of 1776 , B.R. $\$ 8$ (“[I]n all capital or criminal prosecutions a man hath a right to ... a speedy trial by an impartial jury of twelve men of his vicinage, without whose unanimous consent he cannot be found guilty...."). For a more extensive treatment of these provisions, see 1-7 FRANCIS NEWTON THORPE, THE FEDERAL AND STATE CONSTITUTIONS (1909).

${ }^{116}$ Williams, 399 U.S. at 94 (quoting 1 ANNALS OF Cong. 435 Joseph Gales ed., 1789)).

${ }^{117}$ See id. at 94 . The cause for the Senate's concern is not known definitively, since records of this debate are not available. The personal journal of Senator William Maclay served as the primary source of legislative history from the First Senate. Unfortunately, Senator Maclay was ill and absent from the Senate during the entirety of debate on the Sixth and Seventh Amendments. No other direct records of the debate survive. See id. at 95 n.38 (noting the absence of Sen. Maclay).

${ }^{118}$ See id. at 96 . For the text of the pertinent parts of the Amendment, see supra note 5.

119 See Williams, 399 U.S. at 96. Note, however, that although the English term "vicinage" was removed from the text of the Sixth Amendment, it was merely translated, in the Senate version, to its American counterparts "State" and "district," producing no meaningful change to the common-law conceptualization of trial by jury. SeeU.S. CONST. amend. VI.

${ }^{120}$ See Williams, 399 U.S. at 97 (interpreting the language omissions as substantive changes to the common-law right). It could, of course, be argued that the "other accustomed requisites" language was simply removed because it was perceived by the Senate as a redundancy. 
intention not to do so. ${ }^{121}$

This argument raises a number of objections. The entire Senate debate that led to the reworking of the Madison draft apparently stemmed from concerns about the applicability of the vicinage requirement. $^{122}$ A letter written by James Madison establishes as conclusively as possible, given surviving evidence, that the Senate debate centered entirely on this issue and never addressed the issue of jury size. ${ }^{123}$ The vicinage requirement, which developed as an English geographical standard based on England's division into "hundreds" and counties, was a procedural element of jury selection that is clearly distinguishable from substantive components of jury composition and function, such as jury size and verdict unanimity. It was also difficult to translate and apply to an America of different geographical and political divisions. This argument is supported by the Senate's preference for expressing the vicinage right in terms of America's geographical and political subdivisions. ${ }^{124}$ It is almost certain that the common-law jury requirement of "vicinage" was eliminated due to concerns about its clarity and applicability in the American colonies. ${ }^{125}$ The Williams Court's supposition that the Senate also intended to discard the twelve-person jury requirement, however, was poorly substantiated. ${ }^{126}$

The Williams majority defended its interpretation by focusing on

${ }^{121}$ See id. at 96-97 (using the vicinage requirement's history to conclude that such a requirement was not considered essential in the common-law trial by jury).

${ }_{122}$ See Arnold, supra note 74, at 16 ("[T] he failure to include a right to a civil trial was nearly a fatal blow to the new Constitution ... and created a wave of protest.").

${ }^{123}$ James Madison wrote:

[The Senate is] inflexible in opposing a definition of the locality of Juries.

The vicinage they contend is either too vague or too strict a term; too vague if depending on limits to be fixed by the pleasure of the law, too strict if limited to the county. It was proposed to insert after the word Juries [in the proposed amendment], "with the accustomed requisites," leaving the definition to be construed according to the judgment of professional men. Even this could not be obtained .... The Senate suppose ... that the provision for vicinage in the Judiciary bill will sufficiently quiet the fears which called for an amendment on this point.

Letter from James Madison to Edmund Pendleton (Sept. 14, 1789), in 1 LETIERS AND OTHER WRITINGS OF JAMES MADISON 492-93 (New York, R. Worthington 1865).

${ }^{124}$ See generally Williams, 399 U.S. at 95-98 (discussing the meaning associated with the excision of the vicinage requirement).

${ }^{125}$ See supra note 119 and accompanying text.

${ }^{126}$ See Bates, supra note 61 , at 66 (claiming that the convention delegates' lack of debate on a jury requirement for criminal cases may indicate that such a requirement was presumed to be included). 
the Senate's simultaneous removal of the "accustomed requisites" clause, insisting that its excision was intended to have "substantive effect. ${ }^{\text {p27 }}$ As previously noted, however, there is no official record of these debates. ${ }^{128}$ What little legislative history that remains is devoid of any evidence suggesting that the removal of the "accustomed requisites" clause was anything more than a housekeeping action by the Senate to avoid a perceived redundancy. ${ }^{129}$

At the time the Constitution was drafted, the twelve-person unanimous criminal jury was an institution with a nearly fourhundred-year-old tradition in England. It was brought over and immediately integrated, unchanged, into pre-Revolutionary War America. Thus, "it seems clear that to most of the delegates to the Constitutional Convention in 1787, trial by jury in criminal cases meant trial by a body of twelve persons all of whom agreed to the verdict." As Bs Bates has noted, given what is known about the vigorous debate between the Federalists and the Anti-Federalists over civil jury-trial requirements under the Seventh Amendment, ${ }^{131}$ the absence of any recorded discussions about criminal juries before, during, or after the Convention strongly suggests that the longestablished, highly functional common-law tradition of the twelveperson criminal jury was never challenged by the delegates. ${ }^{132}$

The strongest evidence that the Framers tacitly accepted the twelve-person criminal jury is found in the flurry of state-court decisions interpreting the "jury" requirement immediately after the Constitutional Convention. ${ }^{133}$ Curiously, the Court found nothing

${ }^{127}$ Williams, 399 U.S. at 97.

${ }^{128}$ See supra note 117.

${ }^{129}$ See Bates, supra note 61, at 66 ("'[A]ccustomed requisites' were thought to be already included in the concept of 'jury'.... ").

190 Id.

191 See Arnold, supra note 74, at 15-16 (detailing the battle over the Seventh Amendment).

${ }^{132}$ See Bates, supra note 61, at 66.

${ }^{13 s}$ See Foote v. Lawrence, I Stew. 483, 483 (Ala. 1828) ("The term jury is well understood to be twelve men ...."); Vaughn v. Scade, 30 Mo. 600, 604 (1860) ("The term 'trial by jury' was well known and understood at the common law, and in that sense it was adopted in our bill of rights."); Legislative Power to Change Law in Relation to Juries, Op. Justices Supreme Judicial Court, 41 N.H. 550, 551 (1860) ("A jury for the trial of a cause was a body of twelve men ... who ... must return their unanimous verdict ...."); Cancemi v. New York, 18 N.Y. 128, 138 (1858) ("It would be a highly dangerous innovation, in reference to criminal cases, upon the ancient and invaluable institution of trial by jury, and the constitution and laws establishing and securing that mode of trial, for the court to allow any number short of a full panel of twelve jurors ...."); Whitehurst v. Davis, 3 N.C. (2 Hayw.) 113, 113 (1800) 
compelling in this significant body of contemporaneous judicial opinion, and even disregarded its own numerous prior opinions on the subject. ${ }^{134}$ The fact that the Court shunned such substantial evidence supporting the retention of the twelve-person jury standard in favor of a considerably weaker legislative-history argument that scholars have called "twisted"135 and "alarming" "136 arouses suspicion that other motives must have driven the Court to its holding.

The Court admitted in Williams that, given the lack of legislative history on the subject, it was not able "to divine precisely what the word 'jury' imported to the Framers, the First Congress, or the States in 1789." 137 The Court even conceded that "[i]t may well [have been] that the usual expectation was that the jury would consist of 12."138 The Court, however, did not explain why the overwhelming evidence provided by subsequent state constitutional enactments and contemporaneous judicial decisions was not used to ascertain what the missing legislative history might have revealed.

Anticipating the firestorm of criticism that would result from its decision, the Court preempted critics by suggesting that "the most likely conclusion to be drawn [from our decision] is simply that little thought was actually given to the specific question we face today."139 Closer to the truth, perhaps, is what Justice Harlan stated in his concurrence: that a great deal of thought went into the Williams opinion, thought centering primarily on Federalist concerns and a preordained conclusion that the Sixth Amendment right to a twelveperson jury in criminal trials had to be abandoned in the wake of

(interpreting the state constitutional requirement of "trial by jury" to mean that "any innovation amounting in the least degree to a departure from the ancient mode, may cause a departure in other instances, and in the end, endanger or pervert this excellent institution from its usual course"); Work v. State, 2 Ohio St. 296, 304 (1853) ("The number must be twelve, they must be impartially selected, and must unanimously concur....”); Emerick v. Harris, 1 Binn. 416, 426 (Pa. 1808) (interpreting Pennsylvania's constitutional provision that "trial by jury shall be as heretofore," by referring to William Penn's charter of 1682, stating that "all trials shall be of 12 men"); Zylstra v. Corporation of Charleston, 1 S.C.L. (1 Bay) 382, 395-96 (1794) (noting that the structure of the jury, as contemplated at the time of the adoption of the South Carolina Constitution, included 12 members).

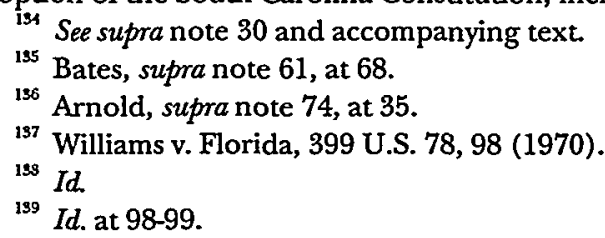


Duncan. $^{140}$

\section{THE CURRENT STATUS OF STATE CRIMINAL-JURY REQUIREMENTS}

The Court's decisions in Duncan, Williams, Ballew, Apodaca, and Burch have permitted a chaotic system of jury requirements to prevail among the states, a system which Justice Harlan, in his Williams concurrence, referred to as "constitutional schizophrenia." ${ }^{141}$ At the time Williams was decided, four states had already departed from the twelve-person jury standard and were allowing juries of fewer than twelve members to decide felony cases. ${ }^{142}$ In addition, a number of other states provided for reduced juries or bench trials for other nonfelonious offenses. ${ }^{143}$

Although the Federal Rules of Criminal Procedure continue to prescribe a twelve-person jury requirement, ${ }^{144}$ these rules only directly apply to the narrow subset of criminal cases tried in federal courts. In all other cases, states are free to decide their own requirements. Today, only seven states specifically require a twelve-member jury in all criminal cases. ${ }^{145}$ Five other states either preserve the

${ }^{140}$ See id. at 134-38 (Harlan, J., concurring in judgment) ("The best evidence of the vitality of federalism is today's decision in Williams.... 'Incorporation' in Duncan closed the door on the debate....").

${ }_{111} I d$. at 136 (Harlan, J., concurring in judgment). For further treatment of these cases, see supra notes 42,57 and accompanying text.

${ }^{142}$ See id. at $99 \mathrm{n} .45$ (citing the relevant constitutional and statutory sections that permitted departures from the twelve-person jury standard in Louisiana, South Carolina, Texas, and Utah).

${ }^{143}$ See id. at 136-42 (Harlan, J., concurring in judgment) (citing three states that allowed nonjury trials in nonfelony cases punishable by more than one year's imprisonment, eight states that permitted six-person juries for cases involving misdemeanors, and five states that allowed bench trials for cases involving misdemeanors).

${ }^{144}$ The Federal Rule provides:

Juries shall be of 12 but at any time before verdict the parties may stipulate in writing with the approval of the court that the jury shall consist of any number less than 12 or that a valid verdict may be returned by a jury of less than 12 should the court find it necessary to excuse one or more jurors for any just cause after trial commences.

FED. R. CRIM. P. 23(b). The Advisory Committee notes made prior to the 1944 adoption of this rule suggest that it contemplates either an agreement before trial to try the case before a jury of fewer than 12 members, or a similar agreement arising during trial in the event that a juror or jurors must be excused from jury service. See FED. $R$. CRIM. P. 23 advisory committee's note.

${ }^{145}$ See ALASKA CONST. art I, $\$ 11$ (requiring an impartial jury of 12 in all criminal prosecutions); TEX. CONST. art. $5, \S 13$ (requiring petit juries in the district courts to be composed of 12, but allowing a nonunanimous verdict of at least nine out of 12 in 
constitutional right to trial by jury "inviolate" or retain state constitutional provisions echoing the language of the Sixth Amendment. ${ }^{146}$ Cases interpreting such language, however, illustrate that jury size has hardly remained inviolate, and any semblance of a consistent standard has been severely eroded. ${ }^{147}$

A number of states have settled the issue by statute, setting the baseline for criminal-jury size at twelve but allowing that number to be reduced with the consent of both parties and the court ${ }^{148}$ This

nonfelony cases); W. VA. CONST. art. III, $\S 14$ (providing that trials of felonies and misdemeanors require a jury of 12 men); HAW. REV. STAT. $\$ 635-26$ (1985) ("The clerk of the court shall draw by lot such jury, to the number of twelve ...."); N.Y. CRIM. PROC. LAW $\S 270.05$ (McKinney 1993) ("A trial jury consists of twelve jurors ...."); N.C. GEN. STAT. § 15A-1201 (1988) ("In all criminal cases the defendant has the right to be tried by a jury of 12 whose verdict must be unanimous."); ME. R. CT. 23(a) (1) ("In all criminal jury cases the jury shall consist of twelve (12) members.").

${ }_{146}$ See ILL. CONST. art. I, $\S 13$ ("The right of trial by jury as heretofore enjoyed shall remain inviolate."); MASS. CONST. pt. 1, art. XII ("[T] he legislature shall not make any law, that shall subject any person to a capital or infamous punishment ... without trial by jury."); OHIO CONST. art. I, $\$ 5$ (amended 1912) ("The right of trial by jury shall be inviolate ...."); OR. CONST. art. I, $\S 11$ (stating that "[i]n all criminal prosecutions, the accused shall have the right to public trial by an impartial jury, ${ }^{n}$ although allowing for agreement among only 10 out of 12 jurors in noncapital felony cases in the circuit courts); TENN. CONST. art. I, $\S 6$ ("[T] he right of trial by jury shall remain inviolate ..."). Ohio courts, however, have ruled that Criminal Rule 23(B), which states that "[i]n misdemeanor cases juries shall consist of eight," does not violate Ohio's constitutional provision. See Columbus v. Boyland, 391 N.E.2d 324, 326 (Ohio 1979) (stating that Rule 23(B) does not alter a defendant's substantive constitutional rights, but "merely prescribes the method by which the substantive right is to be executed").

${ }^{147}$ See, e.g., State v. Bobo, 814 S.W.2d 353, 359 (Tenn. 1991) (interpreting "inviolate" to permit a defendant to consent to a trial with fewer than 12 jurors).

${ }^{148}$ See MONT. CODE ANN. \$ 3-15-106 (1995) ("A trial jury consists of 12 persons or, with the approval of the court, it may consist of any number less than 12 upon which the parties agree in open court."); NEV. REV. STAT. ANN. $\$ 175.021$ (2) (Michie 1992) ("[J]uries must consist of 12 jurors, but at any time before verdict, the parties may stipulate in writing with the approval of the court that the jury consist of any number less than 12 but not less than six."); N.J. STAT. ANN. § 2B:23-1(a) (West 1996) ("Juries in criminal cases shall consist of 12 persons. Except in trials of crimes punishable by death, the parties in criminal cases may stipulate in writing, before the verdict and with court approval, that the jury shall consist of fewer than 12 persons."); S.D. CODIFIED LAWS $\S 23 A-18-2$ (Michie 1988) ("Juries shall consist of twelve members but at any time before verdict the parties may stipulate in writing or orally on the record with the approval of the court that the jury shall consist of any number less than twelve."); WIS. STAT. ANN. $\$ 756.096$ (3) (a) (West 1996) (“A jury in felony cases shall consist of 12 persons unless both parties agree on a lesser number...."); DEL. SUP. CT. CRIM. R. 23(b) ("Juries shall be of 12 but at any time before verdict the parties may stipulate in writing with the approval of the court that the jury shall consist of any number less than 12 or that a valid verdict may be returned by a jury of less than $12 . .$. ); MD. R. CRIM. CAUSES 4-311(b) ("A jury shall consist of 12 persons unless the parties stipulate at any time in writing or on the record that the jury shall consist of any number less than 12."); PA. R. CRIM. P. 1103 (providing that "in all cases the defendant 
arrangement, however, has allowed jury size to become a bargaining chip in pretrial negotiations. ${ }^{149}$ Another group of states requires a twelve-person jury in felony criminal cases but allows the parties and the court to agree to a lesser number in misdemeanor cases. ${ }^{150} \mathrm{~A}$ third group of states now requires a jury of twelve only in their highest-level trial courts. ${ }^{151}$

at any time before verdict may agree, with the consent of his attorney, and approval by a judge of the court in which the case is pending, to be tried by a jury of less than twelve but not less than six," but noting through an advisory comment that this procedure is intended to apply only in situations where a twelve-person jury has initially been sworn); R.I. CT. R. ANN. 23(b) ("Juries shall be of twelve (12) but at any time before verdict the parties may in open court stipulate in writing with the approval of the court that the jury shall consist of any number less than twelve (12)."); VT. R. CRIM. P. 23(b) ("The parties may stipulate in writing that the jury shall consist of any number less than twelve with the approval of the court.");W. VA. CT. R. 23(b) ("Juries shall be of 12, but at any time before verdict the parties may stipulate in writing with the approval of the court that the jury shall consist of any number less than 12 or that a valid verdict may be returned by a jury of less than 12 should the court find it necessary to excuse one or more jurors for any just cause after trial commences.").

${ }^{149}$ See State v. Griffith, 561 So. 2d 528, 537 (Fla. 1990) (describing a prosecutor's waiver of the death penalty in exchange for the defendant's agreement to a trial before a panel of six); State v. Long, No. 01C01-9201CC00026, 1992 WL 389627, at *2 (Tenn. Crim. App. Dec. 31, 1992) (discussing the defendant's submission of his case to a six-person jury in exchange for the prosecutor's stipulation to the authenticity of a transcript of the preliminary hearing).

${ }^{150}$ See CAL. CONST. art. I, $\$ 16$ ("In criminal actions in which a misdemeanor is charged, the jury shall consist of 12 persons or a lesser number agreed on by the parties in open court."); MICH. CONST. art. I, $\S 20$ ("[A]n impartial jury ... may consist of less than 12 jurors in prosecutions for misdemeanors punishable by imprisonment for not more than 1 year...."); N.Y. CONST. art. VI, $\S 18$ a ("The legislature may provide that in any court of original jurisdiction a jury shall be composed of six or of twelve persons... provided, however, that crimes prosecuted by indictment shall be tried by a jury composed of twelve persons ...."); OKLA. CONST. art. II, $\S 19$ ("Juries for the trial of ... felony criminal cases shall consist of twelve (12) persons. All other juries shall consist of six (6) persons. However, in all cases the parties may agree on a lesser number of jurors than provided herein ...."); WYO. CONST. art. I, \& 9 ("A jury in ... criminal cases where the charge is a misdemeanor may consist of less than twelve (12) persons but not less than six (6), as may be prescribed by law.").

${ }^{151}$ See GA. CONST. art. I, para. XI(b) ("A trial jury shall consist of 12 persons; but the General Assembly may prescribe any number, not less than six, to constitute a trial jury in courts of limited jurisdiction ...."); IOWA CONST. art. I, $\$ 9$ ("The right of trial by jury shall remain inviolate; but the General Assembly may authorize trial by a jury of a less number than twelve men in inferior courts ...."); MO. CONST. art. I, § 22(a) ( $[A]$ jury for the trial of criminal ... cases in courts not of record may consist of less than twelve citizens as may be prescribed by law ...."); NEB. CONST. art. I, $\S 6$ ("The right of trial by jury shall remain inviolate, but the Legislature may authorize trial by jury of a less number than twelve in courts inferior to the District Court ....");N.M. CONST. art. I, $\S 12$ ("The right of trial by jury as it has heretofore existed shall be secured to all and remain inviolate. In all cases triable in courts inferior to the district court the jury may consist of six."); S.C. CONST. art. V, $\S 22$ ("The petit jury of the Circuit Court shall consist of twelve members and the number of jurors of other courts 
Many states make a clearer distinction, either by statute or constitutional provision, requiring that juries in all felony cases be composed of twelve members, but allowing all other cases to be tried by a jury of a lesser number, most commonly six. ${ }^{152}$ Indiana has even drawn the line within its felony crimes, requiring a twelve-person jury for some felonies but not for others. ${ }^{153}$ Other states have eroded the twelve-person standard even further by requiring a jury of twelve only in capital cases where a sentence of death or imprisonment for more

must be determined by law."); WASH. CONST. art. I, $\S 21$ ("The right of trial by jury shall remain inviolate, but the legislature may provide for a jury of any number less than twelve in courts not of record ... "); Ky. REV. STAT. ANN. § 29A.280 (Michie 1992) ("Juries for all trials in Circuit Court [higher court] shall be composed of twelve (12) persons. Juries for all trials in District Court [lower court] shall be composed of six (6) persons. In Circuit Court... the parties with the approval of the court may stipulate that the jury shall consist of any number less than twelve (12), except that no jury shall consist of less than six.").

152 See GA. CONST. art. I, para. XI(b) ("A trial jury shall consist of 12 persons; but the General Assembly may prescribe any number, not less than six, to constitute a trial jury in ... misdemeanor cases."); MINN. CONST. art. I, $\S 6$ ("In all prosecutions of crimes defined by law as felonies, the accused has the right to a jury of 12 members. In all other criminal prosecutions, the legislature may provide for the number of jurors, provided that a jury have at least six ...."); COLO. REV. STAT. § 18-1-406 (Supp. 1996) (" $[E]$ very person accused of a felony has the right to be tried by a jury of twelve whose verdict shall be unanimous. In matters involving misdemeanors, the accused is entitled to be tried by a jury of six."); IDAHO CODE $\S 23$ (c) (1996) ("In a felony case the jury shall consist of twelve (12) jurors or any lesser number upon which the party may agree upon the record or in open court. In a misdemeanor case the jury shall consist of six (6) jurors or any lesser number upon which the parties may agree upon the record or in open court."); KAN. STAT. ANN. $\$ \$ 22-3403$ to -3404 (1995) ("A jury in a felony case shall consist of twelve members. However the parties may agree in writing, at any time before the verdict, with the approval of the court, that the jury shall consist of any number less than twelve .... A jury in a misdemeanor . . case shall consist of six members."); N.D. CENT. CODE $\$$ 29-17-12 (1991) ("In all felony cases when a jury is impaneled, a jury must consist of twelve qualified jurors. In class A misdemeanor cases when a jury is impaneled, the jury must consist of six qualified jurors unless the defendant makes a timely written demand for a jury of twelve. In all other misdemeanor cases ... [a] jury must consist of six qualified jurors."); OKLA. STAT. ANN. tit. 22, $\$ 601$ (West 1992) ("The jury consists of twelve persons except that in misdemeanors it shall consist of six persons."); OR. REV. STAT. ANN. $\$ 136.210$ (Michie Supp. II 1996) ("[I]n criminal cases the trial jury shall consist of 12 persons unless the parties consent to a lesser number. ... In criminal cases ... in which the only charges to be tried are misdemeanors, the trial jury shall consist of six persons."); VA. CODE ANN. \$ 19.2-262(2) (Michie 1995) ("Twelve persons from a panel of twenty shall constitute a jury in a felony case. Seven persons from a panel of thirteen shall constitute a jury in a misdemeanor case.").

${ }^{153}$ See IND. CODE ANN. $\$ 35-37-1-1$ (West 1996) ("If a defendant is charged with: murder, a Class A felony, a Class B felony or a Class C felony, the jury shall consist of twelve (12) .... [For] any other crime [including Class D felonies like theft], the jury shall consist of six (6)."). 
than thirty years may be imposed. ${ }^{154}$ States applying these standards, however, frequently allow for these specifically mandated twelveperson juries to be reduced in size with the agreement of both parties and the court. ${ }^{155}$ For example, Mississippi has decided, in light of Williams, that a twelve-person jury is never required. ${ }^{156}$ Statutory provisions in two other states are ambiguous as to the number of jurors required. ${ }^{157}$

The Court's decisions in Williams and its progeny have perpetuated this confusing array of state criminal-jury requirements. Under the present regime, depending on the location of the trial, a

${ }^{154}$ See ARIZ. CONST. art. I, $\S 23$ ("The right of trial by jury shall remain inviolate. Juries in criminal cases in which a sentence of death or imprisonment for thirty years or more is authorized by law shall consist of twelve persons. [In all criminal cases] the unanimous consent of the jurors shall be necessary .... In all other cases, the number of jurors, not less than six, and the number required to render a verdict, shall be specified by law."); CONN. CONST. art. I, $\$ 19$ ("The right of trial by jury shall remain inviolate, the number of such jurors, which shall not be less than six, to be established by law; but no person shall, for a capital offense, be tried by a jury of less than twelve jurors without his consent."); LA. CONST. art. I, $\S 17$ ("A criminal case in which the punishment may be capital shall be tried before a jury of twelve persons, all of whom must concur.... A case in which the punishment is necessarily confinement at hard labor shall be tried before a jury of twelve persons, ten of whom must concur .... A case in which the punishment may be confinement at hard labor or confinement without hard labor for more than six months shall be tried before a jury of six persons, five of whom must concur ...."); UTAH CONST. art. I, $\$ 10$ ("In capital cases the right of trial by jury shall remain inviolate ... [E]xcept in capital cases, a jury shall consist of eight jurors."); ALA. CODE $\$ 18.1$ (c) (1990) ("At the commencement of trial, or at any time before the return of a verdict, and with the consent of the court, the [parties] may stipulate in writing, or in open court upon the record, that the jury may consist of any number of jurors less than twelve (12) and more than five (5) ... In any trial by a jury of less than twelve (12), the verdict must be unanimous. This section does not apply to prosecutions of capital offenses."); FLA. STAT. ANN. § 913.10 (West 1996) ("Twelve persons shall constitute a jury to try all capital cases, and six persons shall constitute a jury to try all other criminal cases.").

155 See supra notes 149-50 and accompanying text.

${ }^{156}$ See MISS. CONST. art. I, $\S 31$ (stating that although the right of trial by jury shall remain inviolate, it does not mandate a twelve-person jury in any court).

157 See MASS. ANN. LAwS ch. 234, $\$ 25-26$ (Law. Co-op. 1986) (failing to state a required number of jurors); N.H. REV. STAT. ANN. $\$ 606: 8$ (1986) (stating that “ [s]ix persons shall constitute a jury for the trial in the superior court of any offense punishable by imprisonment for any period not exceeding one year," but not stating the required number for more serious crimes). But see Opinion of the Justices, 431 A.2d 135, 136-37 (1981) (noting that N.H. Rev. Stat. Ann. $\$ 606: 8$ has never come before the court for its consideration, that "no body of less than twelve men ... would be a jury within the meaning of the constitution," quoting Opinion of the Justices, 41 N.H. 550, 552 (1860), and affirming that "the vitality of [that] conclusion remains today, especially in light of the number of empirical studies that have questioned the impact of the six-member jury on our court system"). 
defendant facing charges of second-degree murder, a noncapital felony in most states, may be guaranteed a jury of twelve, may have to request specifically a jury of twelve, may be tried before a jury of any number between six and twelve, or may face definitively a jury of six. As the next Part will show, the size of the jury this defendant ultimately faces can play a significant, perhaps even definitive, role in the outcome of her trial.

\section{SOCIAL-SCIENCE RESEARCH ON JURY SIZE DEMANDS A TWELVE-PERSON STANDARD}

According to the Williams Court, "the essential feature of a jury ... lies in the interposition between the accused and his accuser of the commonsense judgment of a group of laymen, and in the community participation and shared responsibility that results from that group's determination of guilt or innocence." ${ }^{\text {,158 }}$ Based on this statement of a jury's purpose, the size and composition of the jury is of obvious importance. The Court explicitly recognized this, stating that the "number of the body that makes up the jury .... should ... be large enough to promote group deliberation, free from outside attempts at intimidation, and to provide a fair possibility for obtaining a representative cross-section of the community." ${ }^{159}$ Despite its clear emphasis on these considerations, the Williams Court, citing six socialscience "experiments," found "little reason to think that these goals are in any meaningful sense less likely to be achieved when the jury numbers six, than when it numbers $12,{ }^{161}$ and that the overall reliability of the jury probably was not a function of its size. ${ }^{162}$

\section{A. The Court's Flawed Conclusion in Williams}

The Court's reliance in Williams on the six "experiments" it cited in reaching its conclusions about jury function has generated a

${ }^{158}$ Williams v. Florida, 399 U.S. 78, 100 (1970).

${ }^{159} I d$.

${ }^{160}$ The six social-science experiments cited are: Philip M. Cronin, Six-Member Juries in District Courts, BosToN B.J., Apr. 1958, at 27; New Jersey Experiments with Six-Man Jury, Bull. SEC. JUD. Admin. ABA, May 1966, at 9; Richard H. Phillips, A Jury of Six in All Cases, 30 CoNN. B.J. 354 (1956); Six-Member Juries Tried in Massachusetts District Court, 42 J. AM. JuD. Soc. 136 (1958); Edward A. Tamm, The Five-Man Civil Jury: A Proposed Constitutional Amendment, 51 GEO. L.J. 120 (1962); and Lloyd L. Wiehl, The Six Man Jury, 4 GONZ. L. REV. 35 (1968). See Williams, 399 U.S. at 101 n.48.

${ }^{161}$ Williams, 399 U.S. at 100.

${ }^{162}$ See id. at 100-01. 
firestorm of criticism. ${ }^{163}$ The Court expressly stated that its decision turned not on a question of law or history but on "a functional analysis of the jury purpose." ${ }^{164}$ Thus, the central questions before the Court were whether a jury's representative makeup, deliberative

${ }^{163}$ See, e.g., Bernard Grofman, The Slippery Slope: Jury Size and Jury Verdict Requirements-Legal and Social Science Approaches, 2 LAW \& POL'Y Q. 285, 295 (1980) (agreeing with the criticisms of Saks, supra note 1, of the four "experiments" cited in Williams); David Kaye, And Then There Were Twelve: Statistical Reasoning, the Supreme Court, and the Size of the Jury, 68 CAL. L. REV. 1004, 1004 (1980) (noting that "[i]t was readily shown that [the studies relied upon in Williams] were inconclusive and had little bearing on the question of how size affects jury verdicts"); Richard $O$. Lempert, Uncovering "Nondiscermible" Differences: Empirical Research and the Jury-Size Cases, 73 MICH. L. REV. 643, 645 (1975) (noting that the Court in Williams "considerably overstated" the results of the experiments it cited, and that Professor Zeisel was "gentle with the Court" in not overstating "the majority's extreme disingenuousness in citing these reports as experiments and in relying on them"); Robert T. Roper, Jury Size and Verdict Consistency: "A Line Has to Be Drawn Somewhere"?, 14 L. \& SoC'Y REV. 977, 978 (1980) (noting that the studies cited by the Williams Court were "largely descriptive"); Saks, supra note 1, at 18-20 (discussing the inherently fatal flaws of each experiment); Hans Zeisel, ... And Then There Were None: The Diminution of the Federal Jury, 38 U. CHI. L. REv. 710, 712-15 (1971) [hereinafter Zeisel I] (uncovering personal biases and other problems infecting the conclusions of each of the six experiments); Hans Zeisel, The Waning of the American Jury, 58 A.B.A. J. 367, 367-69 (1972) [hereinafter Zeisel II] (concluding that the Supreme Court used poor reasoning and misinterpreted available data to support its decision); Hans Zeisel \& Shari Seidman Diamond, "Convincing Empirical Evidence" on the Six Member Jury, 41 U. CHI. L. REV. 281, 282 (1974) (noting that the Court "was misled in believing that there was... evidence" in the experiments proving that a reduction in jury size would not affect trial results); Joan B. Kessler, Note, An Empirical Study of Six-and Twelve-Member Jury Decision-Making Processes, 6 U. MICH. J.L. REFORM 712, 714-15 (1973) (noting that the experiments relied on in Williams "are not the product of disciplined, empirical research ... [and] should be viewed with some skepticism ... [since] the evidence is used to support a proposition of great importance to trial by jury"); Lawrence R. Mills, Note, Six-Member and TwelveMember Juries: An Empirical Study of Trial Results, 6 U. MICH. J.L. REFORM 671, 672 (1973) (stating that the evidence relied upon in Williams is "not highly persuasive," because the cited studies represent "merely the personal opinions of several judges, lawyers, and court clerks"); David F. Walbert, Note, The Effect of Jury Size on the Probability of Conviction, 22 CASE W. RES. L. REV. 529, 532 (1971) (concluding that "[n] either the reasoning of the opinion nor the references relied upon support the Court's conclusion.").

Social scientist Hans Zeisel, whose collaborative work, HARRY KALVEN \& HANS ZEISEL, THE AMERICAN JURY (1966), was cited by the Williams majority, was one of the most outspoken critics of the Williams decision. According to Zeisel, the Williams majority badly misinterpreted his findings. See Angelo Valenti \& Leslie Downing, Six Versus Twelve Member Juries: An Experimental Test of the Supreme Court Assumption of Functional Equivalence, I PERS. \& SOC. PSYCHOL. BULI. 273, 273 (1974) ("Zeisel ... who along with Kalven wrote The American Jury, a work heavily cited by the Supreme Court in the [Williams] decision, argued that the Court had misinterpreted the findings of The American Jury and that 6 member juries are not functionally equivalent to 12 member juries.").

164 Saks, supra note 1, at 18. 
processes, likelihood of conviction, minority ability to resist majority pressure, and verdict reliability would differ significantly between sixand twelve-person juries. ${ }^{165}$ Despite the fact that, as Michael Saks has pointed out, "the opinion stated that the case entirely turned on this set of empirical questions," the Court's treatment of these issues spanned only three paragraphs of the twenty-six-page majority opinion. ${ }^{166}$

More critically, however, the Court's cursory evaluation of the six social-science "experiments" was deeply flawed, leading to the inaccurate conclusion that there were "no discernible difference[s]" between six- and twelve-person juries on the aforementioned factors. ${ }^{167}$ Closer inspection of the experiments cited in footnote forty-eight of the Williams majority opinion reveals that they are, empirically speaking, entirely unreliable, and in fact are not "experiments" at all."

In the first of these articles, Judge Lloyd Wiehl cited only Charles Joiner's anecdotal reports in Civil Justice and the Jury, ${ }^{169}$ and Judge Wiehl's own unsupported assertions, to conclude that six- and twelveperson juries deliberate identically. ${ }^{170}$ Judge Wiehl's article offered no empirical justification for such a conclusion. ${ }^{171}$ Similarly, Judge Edward Tamm relied only on his "satisfactory" experiences presiding over five-person juries hearing condemnation trials in the District of Columbia to draw his conclusions about the deliberative equivalence of six- and twelve-person juries. ${ }^{172}$ Consequently, Judge Tamm's article is devoid of the empirically verifiable evidence necessary to make his claim anything more than anecdotal. ${ }^{173}$

The Philip Cronin article, which reports the results of an

${ }^{165}$ See id; see also Williams, 399 U.S. at 100 (establishing these purposes as the essential functions and features of a jury).

${ }^{166}$ Saks, supra note 1 , at 18.

${ }^{167}$ Williams, 399 U.S. at 101.

${ }^{163}$ See, e.g., Lempert, supra note 163, at 645 (noting the majority's "extreme disingenuousness in citing these reports as experiments and in relying on them").

${ }^{169}$ Charles W. JOINER, CIVIL JUSTICE AND THE JURY $82-83$ (1962) (arguing that there is no evidence to show that jury deliberation requires 12 people).

${ }^{170}$ See Wiehl, supra note 160 , at $39-44,39$ ("It seems that a six-man jury could deliberate equally as well [as a twelve-man jury] ....").

${ }^{171}$ See Zeisel I, supra note 163, at 714 (noting that Wiehl's article, supra note 160 , "does not have any evidence" for its conclusion).

${ }^{172}$ See Tamm, supra note 160 , at $136-38$ (discussing his 14 years of experience presiding over five-person juries).

${ }^{173}$ See Zeisel I, supra note 163, at 714-15 (suggesting that specific data is needed to make accurate findings in the realm of social sciences). 
experimental reduction in civil-jury size sanctioned by the Massachusetts legislature, ${ }^{174}$ suffers from the same lack of empirically verifiable evidence that plagues Judge Tamm's article. ${ }^{175}$ Although forty-three trials were observed, conclusions as to the equivalence of six- and twelve-person juries were based solely on the personal perceptions of the court clerk and three attending lawyers. ${ }^{176}$

The fourth "authoritative" study cited as support by the Williams Court was a duplicative review of the Massachusetts experiment previously described. ${ }^{177}$ The fifth study provides even less authority than the previous studies. Although it stated that "the Monmouth County Court had experimented with the use of a six-man jury in a civil negligence case," the jury's effectiveness. ${ }^{179}$ Finally, Judge Richard Phillips's article merely suggested the potential economic advantages to be derived from the reduction in jury size from twelve to six in all noncapital cases. ${ }^{180}$ Judge Phillips, however, never addressed the potential functional consequences of such a reduction. ${ }^{181}$ Taken individually or collectively, these "authoritative experiments" provided "scant evidence by any standards," 182 because "[n]ot one of the references even began to address competently the empirical questions the Court

${ }^{174}$ See Cronin, supra note 160, at 27-29 (assessing the Massachusetts experiment with six-person juries in district courts and noting generally favorable responses from participating lawyers).

${ }^{175}$ Zeisel I, supra note 163, at 714 (discussing the Massachusetts study of six-person juries).

${ }^{176}$ See Saks, supra note 1, at 18; Zeisel I, supra note 163, at 714. One of the three observing lawyers later testified that he found there to be no significant differences between the verdicts of smaller juries and twelve-person juries because " $[t]$ here seems to be no particular reason why the size of a finding would be affected by [the size of the jury]." Zeisel I, supra note 163, at 714. Even disregarding the fact that this testimony employs circular reasoning, it also suggests that this observer failed to even consider the possibility that changes in jury size could affect jury deliberations and verdicts.

${ }^{17}$ See Six-Member Juries Tried in Massachusetts District Court, supra note 160, at 136 (concluding that "the lawyers who use the District Court, as well as the clerk, report that the verdicts [of six-member juries] are no different than those returned by twelvemember juries"). As has been stated previously, these reports were based solely on qualitative observations and were devoid of any empirical grounding.

${ }^{178}$ New Jersey Experiments with Six-Man Jury, supra note 160, at 6.

${ }^{179}$ See Zeisel I, supra note 163, at 71415.

180 See Phillips, supra note 160 , at 357 (estimating a savings to Connecticut of approximately $\$ 75,000$ per year in 1950 s' dollars).

${ }_{181}$ See id. at 357 ("[B]oth the complete jury trial and the innumerable partial jury trials would be shortened and made more businesslike with a jury limited to six.").

${ }^{182}$ Zeisel I, supra note 163 , at 715. 
posed for itself.",183

Additionally, in footnote forty-nine of the Williams opinion, the Court made a number of errors interpreting well-established, empirical social-science research-mistakes that Saks has labeled even "more incredible" than the Court's previous misinterpretations. ${ }^{184}$ For example, one of the most widely recognized studies ${ }^{185}$ in social psychology focusing on conformity and peer influence has established that the presence of a single ally is the most powerful facilitator of minority resistance to majority pressure. ${ }^{186}$ Applied to the jury context, the finding suggests that a panel divided ten to two will not be functionally identical to a panel split five to one despite the proportional equivalence of the two juries, because a minority viewpoint defended by an ally (the ten-to-two case) can be expected to offer significantly greater resistance to conformity pressure from the majority than the five-to-one split where the dissenting juror stands alone. ${ }^{187}$ It is the absolute size of the minority faction, not the proportional equivalence of the minority to the majority, that determines the minority faction's ability to resist pressure to conform. ${ }^{188}$ The Williams Court used this research ${ }^{189}$ to conclude erroneously that "[s] tudies of the operative factors contributing to small group deliberation and decisionmaking suggest that jurors in

${ }^{183}$ Saks, supra note 1 , at 18 (emphasis added).

${ }^{184} I d$.

185 See Lempert, supra note 163, at $674 \mathrm{n} .94$ (stating that the results of this study have been corroborated by others and are "generally accepted by socialpsychologists").

${ }^{186}$ See S.E. Asch, Effects of Group Pressure upon the Modification and Distortion of Judgments, in GROUP DYNAMICs 189, 199 (Dorwin Cartwright ed., 2d ed. 1960) (summarizing the results of his experiment with group pressure); see also Charles A. Kiesler, Group Pressure and Conformity, in EXPERIMENTAL SOCIAL PSYCHOLOGY 233, 257 (Judson Mills ed. 1969) (corroborating the Asch findings).

${ }^{187}$ See Saks, supra note 1, at 19 (explaining the Court's misinterpretation of this research).

${ }^{188}$ See Asch, supra note 186, at 199 (" [T] he majority effect is a function of the size of group opposition."); Kiesler, supra note 186, at 257 (supporting Asch's finding that the absolute size of the minority is determinative); Saks, supra note 1 , at 19 (stating that numerous studies have "found that it is the absolute rather than the relative size of the opposition that determined factional influence.").

${ }^{189}$ In Williams, the Court cited The American Jury and an unpublished thesis to support the conclusion that minority jurors are influenced by the proportional size of the majority. 399 U.S. at 101 n.49. Hans Zeisel, co-author of The American Jury, protested the Court's misinterpretation of the work. See supra note 163. The Williams Court also referenced the Asch study, which at the time of the Williams decision, was already the widely corroborated and accepted position in the field, but dismissed its implications. See Williams, 399 U.S. at 101 n.49. 
the minority... are likely to be influenced by the proportional size of the majority aligned against them ${ }^{\$ 190}$ - a result "exactly the opposite" of what Asch's research found. ${ }^{191}$

Finally, the Williams Court took up the issue of community representation. Without a single authority in its favor, the Court concluded that, "while in theory the number of viewpoints represented on a randomly selected jury ought to increase as the size of the jury increases, in practice the difference between the twelveman and the six-man jury in terms of the cross-section of the community represented seems likely to be negligible." 192

Saks pointed out that, in reaching this conclusion, the Court "ignored what is obvious to every social scientist: that when sampling from heterogeneous populations, sample size determines how well minority groups in the population will be represented."193 Saks illustrated, through simple statistical probability, that reducing a jury panel from twelve members to six members would cause a significant reduction in minority representation on the smaller panel. ${ }^{194} \mathrm{He}$ noted, however, that the use of statistical-sampling theory alone produces a certain margin of error, and thus, the "sincere empiricist" would still require "empirical evidence" before accepting its conclusions. ${ }^{195}$ Consequently, Saks conducted a series of controlled studies involving twelve- and six-member juries whose members were drawn from a representative population which was ten percent African-American. His empirical findings revealed that the actual difference in minority representation on twelve- and six-member juries was even more pronounced than the sampling theory had suggested. ${ }^{196}$ Few researchers, Saks concluded, would consider this

${ }_{190}^{190}$ Williams, 399 U.S. at 101 n.49 (emphasis added).

191 See Saks, supra note 1 , at 19 (stating that a number of empirical studies contradict the conclusion of the Williams Court); see also Asch, supra note 186, at 198 (reaching the conclusion that the absolute size, not the proportional size, of the minority opposition was the determinative factor); MICHAEL J. SAKS, JURY VERDICTS 1618 (1977) (discussing, in detail, the Court's misinterpretation of these studies).

${ }^{192}$ Williams, 399 U.S. at 102.

193 Saks, supra note 1, at 19.

${ }^{19}$ See $i d$. (illustrating that in a given community population with a $10 \%$ minority composition, sampling theory predicts that $72 \%$ of twelve-member panels will contain one or more minority members, while only $47 \%$ of six-member juries will).

195 See id. (noting the limitations of sampling theory).

196 See SAKS, supra note 191, at 90-91 (showing that instead of the $72 \%$ to $47 \%$ contrast in minority membership on twelve- and six-person juries, respectively, predicted by sampling theory, Saks's empirical studies place the contrast at $89 \%$ to $41 \%)$. 
difference to be, in the words of the Williams Court, "negligible."197

The Williams Court's use of dubious authority and misinterpretation or outright dismissal of widely corroborated socialscience research in justifying a departure from the twelve-person criminal jury standard sparked outrage in the social-science community. ${ }^{198}$ The years following the Williams decision bore witness to "a veritable industry" nearly every possible effect that a reduction in panel size might have on jury function. ${ }^{200}$

\section{B. The Battle Between Law and Social Science in Colgrove v. Battin}

After weathering intense criticism from social scientists and leaders of the legal profession following Williams, the Court in Colgrove v. Battin ${ }^{201}$ was more cautious in its references to socialscience research. ${ }^{202}$ Unfortunately, because empirically principled research often requires two to five years from initiation to publication, ${ }^{203}$ only four subsequent studies involving jury size had been conducted by the time Colgrove came before the Court. ${ }^{204}$

Although the fact that the Colgrove Court took pains to locate and consider only empirical studies "might be viewed as progress," mere fact that a social-science study involves empirical research does

${ }^{197}$ See Saks, supra note 1 at 19 (concluding that representational differences between twelve- and six-person juries are not negligible as the Williams Court has stated).

${ }^{193}$ See supra note 163 and accompanying text (highlighting the social-science community's response to the Williams decision).

${ }^{199}$ Roper, supra note 163 , at 978.

${ }^{200}$ For a comprehensive bibliography of these jury studies, see Norbert L. Kerr \& Robert L. MacCoun, The Effects of Jury Size and Polling Method on the Process and Product of Jury Deliberation, 48 J. PERSONALITY \& SOC. PSYCHOL. 349, 362-63 (1985).

${ }^{201} 413$ U.S. 149 (1973). The composition of the Court had changed since the Williams decision was announced. Justice Black, who wrote a partial dissent in Williams, retired and was replaced by Justice Powell. Likewise, Justice Harlan, who wrote a blistering dissenting opinion in Baldwin v. New York, 399 U.S. 66 (1970), a companion case to Williams, favoring the retention of the twelve-person jury, retired, and was replaced by Justice (now Chief Justice) Rehnquist.

${ }^{202}$ See Saks, supra note 1 , at 19 (stating that this time around, the "Court did look at empirical studies and did understand the stated findings.")

${ }^{203}$ Conversation with Dorothy G. Singer, Ed.D, research scientist and Co-Director of the Yale Television Research and Consultation Center (Nov. 1, 1993).

${ }^{204}$ See Saks, supra note 1 , at 19.

${ }^{205}$ Id. 
not render it per se authoritative. ${ }^{206}$ The results of an empirical study are only as good as the methodology used to derive them. ${ }^{207}$ Although empirical studies conducted with flawed methodologies are not authoritative, they can be dangerously misleading because their empirical structure renders them instantly more credible. ${ }^{208}$ Whether due to a lack of prepublication peer-review by psychological researchers ${ }^{209}$ or due to a rush to publish "hot" material, the four studies ${ }^{210}$ which the Court in Colgrove claimed provided "convincing empirical evidence" to buttress the Williams decision actually "said much less than the Court thought they were saying" due to their inherent and rampant methodological problems. ${ }^{21}$

The first of these four studies was a 1973 examination conducted by Gordon Bermant and Rob Coppock, which found no overall differences in verdict frequency linked to jury size. ${ }^{212}$ The absence of such a finding, however, was likely attributable to a "confound" masking such a difference. The study involved 128 juries composed

${ }^{206}$ See Zeisel \& Diamond, supra note 163, at 281 (asserting that the validity of empirical studies differs, and the intelligent use of empirical evidence requires a critical evaluation of the research).

${ }^{207}$ See Saks, supra note 1 , at 19 ("The importance of method cannot be overstressed.").

${ }^{209}$ See id. ("Studies using poor methods tell one nothing; but they can seriously mislead because their findings still may properly be called 'empirical.").

${ }^{209}$ None of the four empirical studies cited by the Colgrove Court was published in a psychology journal, where peer-review by a board of psychological researchers is an inherent part of the article-selection process.

${ }^{210}$ The four studies were: INSTITUTE OF JUDICIAL ADMINISTRATION, A COMPARISON OF SIX- AND TWELVE-MEMBER CIVIL JURIES IN NEW JERSEY SUPERIOR AND COUNTY COURTS (1972) [hereinafter IJA], cited in JOHN MONAHAN AND LAURENS WALKER, SOCIAL SCIENCE IN LAW 191 \& n.13 (2d ed. 1990) (finding no significant differences in tendency toward verdict outcome between six- and twelve-person juries in jurisdictions where litigants were permitted to choose jury size); Gordon Bermant \& Rob Coppock, Outcomes of Six-and Twelve-Member Jury Trials: An Analysis of 128 Civil Cases in the State of Washington, 48 WASH. L. REV. 593, 596 (1973) (finding that "six-and twelve-member juries behaved identically in the cases under consideration"); Kessler, supra note 163, at 712 (finding no significant difference in verdicts of six- and twelve-person mock juries evaluating a videotaped trial); and Mills, supra note 163, at 710-11 (finding no discernible differences in jury decisions when comparing groups of twelve-member jury decisions and six-member jury decisions).

${ }^{211}$ Saks, supra note 1 at 19.

${ }_{212}$ See Bermant \& Coppock, supra note 210, at 596.

${ }^{213}$ A confound, typically the result of methodological flaws in the experimental design, occurs when several potential causes for a given result are allowed to vary together. Consequently, it is impossible to discover which of the potential causes is responsible for a discerned change in result. See id. (explaining how a confound creates weaknesses in a study). 
of either six or twelve members. Those juries, however, also heard 128 different cases, with 128 different sets of facts, some or all of which might have been severely skewed toward either the plaintiff or the defendant. The cases also all involved different parties, different judges, and different requests for damages. Finally, the attorneys in each of the cases were allowed to pre-select their jury size prior to the commencement of trial proceedings. ${ }^{214}$ Given that lawyers prefer larger juries in complex cases, or when higher damages are sought, ${ }^{215}$ this feature alone could have masked a potential difference in the way juries ruled. When combined with different facts, damage amounts, judges, and parties, one cannot tell which factor was responsible for the experimental finding. ${ }^{216}$ As Saks pointed out, a careful reading of the Bermant and Coppock study shows that:

When the researchers saw a difference they didn't like, they explained it away by pointing to the confound. When they saw a non-difference they did like, they made believe the confound wasn't there. Given the procedures by which the data were collected and analyzed, one is simply unable to know what effect, if any, jury size did have.

Flaws aside, the study also was merely correlational-measuring only the frequency of guilty and not-guilty verdicts across six- and twelve-person juries in 128 separate trials, each with different parties and different evidentiary facts. ${ }^{218}$ Results of such a correlational study are of limited utility because any number of "artifacts" ${ }^{219}$ hiding in the facts or procedures of the individual trials might produce the result, and "alternate interpretations... undermine [any] conclusion that jury size does not causally influence jury performance."220 This early study is now largely archival, as its widely recognized methodological flaws and correlational structure have rendered its conclusions unauthoritative. ${ }^{221}$

${ }^{214}$ See Bermant \& Coppock, supra note 210, at 595-96 (establishing the governing aspects of the study); see also REID HASTIE ET AL., INSIDE THE JURY 33 (1983) (iterating the problematic aspects of the Bermant \& Coppock study); Saks, supra note 1, at 19 (noting that the ability of attorneys to pre-select their jury size may have had a distorting effect on the study).

215 See HASTIE ET AL., supra note 214, at 33.

${ }^{216}$ See Saks, supra note 1, at 20.

${ }^{217} I d$

${ }^{218}$ See Bermant \& Coppock, supra note 210 , at 594-95.

${ }^{219}$ An "artifact" is an artificial result produced by flawed experimental methodology or the confluence of uncontrolled factors.

${ }^{220}$ HASTIE ET AL., supra note 214, at 33.

221 See id. at 32. 
The Institute of Judicial Administration ("IJA") study, although somewhat broader in scope, ${ }^{222}$ suffered from similar methodological problems. ${ }^{223}$ Although the IJA study reported that twelve-member juries required about twice as much trial time, deliberated longer, and awarded triple the damages that average six-person juries awarded, the researchers attributed these differences to the lawyers' case selections. ${ }^{224}$ Once again, the bias introduced by the lawyers' systematic pretrial selection of six- or twelve-person juries to correspond with cases of differing complexity and damage requests operated as a confound. As a result, no definitive conclusions can be drawn. ${ }^{225}$

Attorney case-selection bias was eliminated in the Michigan study by timing the experiment to occur during the six-month period just prior to and immediately following the Michigan legislature's institution of compulsory six-member juries in all civil trials. ${ }^{226}$ Unfortunately, the legislature simultaneously created a mediation board to encourage pretrial settlements in these cases. As a result, lawyers still may have self-selected the more complex or expensive cases for a hearing before this board, rather than trusting such cases to an arguably less favorable ${ }^{227}$ six-person jury. ${ }^{228}$ Since there is no data to show that such pre-selection did not occur, it is possible that the six-member juries heard only the simpler cases, creating a confound in the study. The study's conclusion that there is no difference in verdict outcome between six and twelve-person juries is therefore unreliable. While the study offered no proof that there was a difference in verdict outcome attributable to jury size, the change in the types of cases heard by six-member juries, via the siphoning off of certain cases by mediation-board settlement, might have masked such a difference. ${ }^{229}$

${ }^{222}$ The IJA study, in addition to charting verdict distributions between six- and twelve-person juries, also considered the effects of case type and damage amounts requested and received. See IJA, supra note 210 , at $191 \&$ n.13.

${ }^{223}$ See HASTIE ET AL., supra note 214, at 33 (critiquing the study); Saks, supra note 1, at 19 (same).

224 See IJA, supra note 211 , at 191 \& n.13.

${ }^{225}$ See HASTIE ET AL., supra note 214, at 33 (dismissing the results of the IJA study); SAks, supra note 191, at 191 (same).

${ }^{226}$ See HASTIE ET AL., supra note 214, at 33.

${ }^{227}$ In the IJA study, lawyers favored large juries for more complicated trials or cases with larger damage requests. See IJA, supra note 211 , at 191 \& n.13.

${ }_{223}$ See Saks, supra note 1 , at 19 (noting that lawyers well may have used the mediation board in these cases to keep them away from a smaller jury).

${ }^{229}$ See id. 
The presence of such confounds subsequently has caused most social scientists to dismiss the results of the prior three studies. ${ }^{230}$ As Saks noted, confound avoidance requires a properly designed "controlled study," where the experimental methodology allows for systematic, individual changes in the variables of interest. ${ }^{23}$

The Joan Kessler study offered the most progressive experimental opportunity for a reliable finding of jury-size differences at the time it was conducted. ${ }^{232}$ In this experiment, an identical videotaped case was presented to a pool of jurors randomly assigned to six- or twelveperson panels. All other variables were controlled to assure that the only difference between the assembled panels was their size. ${ }^{239}$ Unfortunately, two careless but critical problems doomed the otherwise sound Kessler experiment.

First, the videotaped trial was so one-sided that none of the assembled juries disagreed on the proper verdict. Without variability in verdict outcome overall, verdict outcome could not possibly have differed between six- and twelve-member panels. ${ }^{234}$ Second, and independent of the verdict-variability problem, the study's sample size was too small to produce any reliable findings. ${ }^{235}$ As Saks observed, "[a]ll competent social scientists know that the ability of a study to detect effects is determined in part by the sample size. A good way to guarantee that a study will find 'no differences' is to use a very small sample size."236 Thus, although otherwise well-designed, the Kessler

${ }^{230}$ See HASTIE ET AL., supra note 214, at 32 (stating that "methodological flaws make any conclusions from these studies tentative at best"); see also SAKS, supra note 191, at 38 (asserting that the four studies suffer from a variety of classical flaws in research design); Grofman, supra note 163, at 288 (agreeing with the conclusions of Zeisel \& Diamond); Lempert, supra note 163, at 646 (same); Zeisel \& Diamond, supra note 163, at 283 (dismissing the conclusions of the four empirical studies cited in Colgrove as unauthoritative).

${ }^{231}$ See Saks, supra note 1, at 19 (discussing the construction of "true experiments").

${ }^{222}$ See id. (noting the increased reliability of "true experiments" which can avoid confounds more readily).

${ }^{233}$ See Kessler, supra note 163, at 719-22 (discussing experimental methodology).

${ }^{234}$ See id. It is a fundamental principle of social-science research that if there is no variability in the dependent variable (here, verdict outcome), it is impossible to see how variations in independent variables (such as jury size) affect the dependent variable, and thus, an experiment is rendered essentially worthless. As a result, most experimenters conduct pilot studies to test their experimental stimuli in order to avoid such problems.

${ }^{235}$ Only eight twelve-member juries and eight six-member juries were assembled. See Kessler, supra note 163, at 719 (discussing experimental methodology).

${ }^{236}$ Saks, supra note 1, at 19 (noting that a sample size of 16 juries could reliably detect differences in proportion of jury verdicts between groups only if that difference 
study's two central flaws were, as Saks concluded, "adequate to insure that the only finding that could have come from this study was no difference between the different-sized juries." ${ }^{237}$

Research and jurisprudence concerning jury size is riddled with irony. The four empirical studies cited in Colgrove all criticized the Williams Court for departing from the twelve-person jury standard without the support of empirical evidence. Presumably, each of these studies was conducted to provide just such evidence. Due to their rampant methodological errors, however, these studies "contribute[d] nothing" ${ }^{238}$ to the debate. The even greater irony, however, is that the Court, on guard after the critical drubbing it took in the wake of Williams, needed empirical evidence to support the Williams holding, and embraced these flawed studies in Colgrove as "convincing empirical evidence." 239 Although the experimental researchers were partially responsible for these errors, the expertise required to detect logical flaws in experimental research is modest, and was certainly not beyond the ability of the Justices of the Supreme Court. $^{240}$ Summing up the state of affairs after Colgrove, Saks concluded, "the Court and the respective advocates have consistently failed to exercise the modest expertise that could have prevented this remarkable incompetence." 241 As a result, "[t] he Court currently believes the matter of equality of performance for different-sized juries is now well-established, when in truth there is still no evidence to support such a conclusion."242

\section{The Functional Superiority of the Twelve-Person Jury}

As previously noted, principled social-science experiments often require three to five years from inception through publication. ${ }^{243}$

was $25 \%$ or higher). Since it is clear that a $25 \%$ difference in verdict outcome is much higher than most scientists would consider a significant floor-differential to be, the Kessler study was of limited utility from the outset.

${ }^{237} I d$. (citing the findings of the Kessler study).

${ }^{239} I d$.

${ }^{239}$ See Colgrove v. Battin, 413 U.S. 149, 159 n.15 (1973).

${ }^{240}$ See Zeisel \& Diamond, supra note 163, at 392 ( $"[\mathrm{~T}]$ he courts know how to consider critically traditional types of evidence presented in adversary proceedings."); see also Saks, supra note 1, at 19 (noting the Justices' ability to detect flaws in experimental research).

${ }^{241}$ Saks, supra note 1, at 19.

${ }^{242} I d$. (emphasis added).

${ }^{243}$ See supra text accompanying note 203. 
Consequently, the vast majority of the "veritable industry" about jury size inspired by Williams was not published until the mid1970s, after Colgrove was decided. The consistent findings delivered by these studies probing the differences in the "essential feature[s]" of the jury as cited in Williams ${ }^{245}$ now clearly establish the functional superiority of the twelve-person jury. ${ }^{246}$ Having committed itself in Williams to a functional test of jury performance dependent on a "combination of measurable factors," choice but to "evaluate the empirical responses of scholars and social science investigators" to those factors. ${ }^{248}$

\section{General Findings of Small-Group Research}

Conclusions based on small-group research make important contributions to scholars' theoretical understandings and initial hypotheses about the functional differences between six- and twelvemember groups. Some well-known research findings, which have been sufficiently corroborated to provide reliable information about the way individuals function in groups, can thus provide critical insight into the functional characteristics of different-sized juries. ${ }^{249}$ For example, the now-classic conformity studies of Muzafer Sherif ${ }^{250}$

${ }^{244}$ Roper, supra note 163 , at 978.

245 See Williams v. Florida, 399 U.S. 78, 100-01 (1970) (establishing differences in the jury's reliability, representative makeup, deliberative processes, likelihood of conviction, and minority ability to resist majority pressure as the essential concerns in examining differences between twelve-person juries and juries of smaller size).

${ }^{246}$ See Grofman, supra note 163, at 300-01 (stating that, based on available data, "a strong case for the superiority of twelve-member juries over six-member juries can be made").

${ }^{247}$ For discussion of the "measurable factors" the Court considered important, see supra notes 158-59 and accompanying text.

${ }^{248}$ Tanke \& Tanke, supra note 43 , at 1131.

249 See id; see also Lempert, supra note 163, at 666-67 (discussing the role that smallgroup research can play in the jury size debate). Lempert notes that the methodology of small-group research limits, to some degree, its overlay onto the jury size problem. Much of the small-group research is based on the findings of experiments conducted on students who face much different problems than those faced by juries. Furthermore, much of the small-group research focuses on the differences between groups of two and seven, rather than groups of six and 12. See id.

${ }^{250}$ See Muzafer Sherif, Group Influences upon the Formation of Norms and Attitudes, in Readings in Social Psychology 77, 90 (T. Newcomb \& E. Hartley eds. 1947) (illustrating that individuals' judgments tend toward conformity when placed in a group context); see also A. PAUL HARE, HANDBOOK OF SMALl GROUP RESEARCH 20-21 (2d ed. 1976) (discussing the results of the famous nonmoving light experiment where individuals were placed in a dark room, shown a pinpoint of light which did not move, and asked how far the light moved. Individuals were then placed back in the 
and S.E. Asch ${ }^{251}$ provided the foundation for jury-specific studies of minority conformity to majority pressure. These early experiments conclusively demonstrated the remarkable degree to which individual group members could be pressured to conform to the will of the majority, ${ }^{252}$ the importance of an ally in increasing the likelihood that a single dissenter will hold out against a majority, ${ }^{253}$ and the fact that, as group size increases, "there is an increase in the opportunities to form subgroup coalitions representing minority opinions."

Another early report summarized the results of thirty-one separate studies on group size and concluded that when analyzing group performance and group productivity, under no conditions were smaller groups superior. The authors noted that the size of a group should be taken into account in any theory of group behavior. $^{255}$ Richard Lempert suggested that the superiority of larger

dark in groups. When asked how far the nonmoving light had moved, prior individual judgments gave way to a group norm).

${ }_{251}$ See Asch, supra note 186 (describing the results of his now-famous line-length experiment where the influence of an arranged, intentionally incorrect but unanimous group opinion about the length of drawn lines on a card was enough to dissuade an individual from responding one-third of the time with her correct presentsense impressions); Solomon E. Asch, Opinions and Social Pressure, 193 SCI. AM., Nov. 1955, at 31, 31-35. In this second experiment, Asch illustrated that if a naive subject was given an ally who gave the true estimate of the line length, the naive subject's conformity to group pressure was significantly reduced. Further, if the ally joined with the naive subject during the experiment, the subject acted independent of the majority. See id. These findings have been widely corroborated and are now generally accepted by social psychologists. See HARE, supra note 250, at 32-33 (cataloguing studies which corroborate the Sherif/Asch findings); Lempert, supra note 163, at 674 n.94 (reiterating the acceptance of the Sherif/Asch study).

${ }^{252}$ See HARE, supra note 250 , at 20-21 (describing the nonmoving light experiment's illustration of group influence on individual behavior); Asch, supra note 186, at 199 (stating that, in the line-length experiment, although a substantial proportion of individuals retained their independence, a substantial proportion modified their responses in accordance with the majority); Sherif I, supra note 250, at 78-86 (citing the nonmoving light experiment as an example of how societal norms are defined by contact with others).

${ }^{253}$ See HARE, supra note 250, at 32-33 (noting that experiments show that having one person support the subject's position increases the likelihood of the subject holding out against the majority); Asch, supra note 251, at 34 (stating that " $[\mathrm{t}] \mathrm{he}$ presence of a supporting partner depleted the majority of its power"); Lempert, supra note 163 , at 674 (noting that experiments show that support from an ally prevents the subject from conforming even though the majority was very large).

${ }^{254}$ HARE, supra note 250, at 33 (citing A. Paul Hare, A Study of Interaction and Consensus in Different Sized Groups, 17 AM. SoC. REV. 261, 261-67 (1952)).

${ }^{255}$ See Edwin J. Thomas \& Clinton F. Fink, Effects of Group Size, 60 PsYCHOL. BuLL. 371,373 (1963) (reviewing the results of ten experimental studies which dealt with the effects of group size on group performance in problem solving and finding a positive correlation between group size and group performance). 
groups over smaller groups, in theory, derived from the "participation of a greater number of individuals with more diverse viewpoints in the problem-solving effort." ${ }^{256}$ Research has demonstrated that larger groups perform better in situations where the quality of the group solution is measured by the sum-total contribution of all members. ${ }^{257}$ Given that the Williams Court explicitly valued representative community participation as one of the "essential features" of the jury, ${ }^{253}$ the Court should agree that a jury decision which allows the contribution of a broader cross-section of the community is, in that sense, of "higher quality."

Early research on group size also illustrated that in fact-intensive or observational situations, larger groups outperformed smaller groups because there were more individual members available to provide critical contributions at different stages of the process. ${ }^{259}$ Thus, where memory is important, a larger group is more likely to recall crucial facts vital to the proper solution of the problem. ${ }^{260}$ This result can be extended to juries, since recall of facts and in-court observations is crucial to the deliberative process. ${ }^{261}$ Consequently, "larger juries are likely to be superior to smaller juries where memory or a good understanding of facts and instructions is crucial to the deliberative process." ${ }^{262}$

Some areas of small-group research, however, seemingly suggest potential advantages of smaller juries. For example, group research has shown that larger groups are harder to coordinate and that smaller groups are better able to resolve problems requiring a consistent strategy or coordinated movements. ${ }^{263}$ The same body of work, however, also demonstrates that some larger groups are better

${ }^{256}$ Lempert, supra note 163 , at 685.

257 See id. at 686.

${ }^{25 s}$ Williams v. Florida, 399 U.S. 78, 100 (1970).

${ }^{259}$ See William L. Faust, Group Versus Individual Problem-Solving, 59 J. ABNORMAL \& SOC. PSYCHOL. 68, 77 (1959) (explaining that groups perform better in memory-based experiments because individuals forget different elements, but working together, they can complete the task).

${ }^{260}$ See Harold H. Kelley \& John W. Thibault, Group Problem Solving, in 4 HANDBOOK OF Social PSYCHOLOGY 59, 65-66 (Gardner Lindzey \& Elliot Aronson eds., 2d ed. 1969) (stating that experiments show group-recall scores to be higher than the best individual scores).

${ }^{261}$ See Lempert, supra note 163 , at $686-87$ ( “[A] large group is more likely to contain members who recall crucial facts at each stage of the problem-solving activity.").

${ }^{262}$ Id. See id. at 691. 
at solving complex human-relations problems. Since jury deliberations involve these complex problem-solving issues, and since the very nature of deliberation often precludes coordination of the group as a whole, this finding actually supports the use of twelve-person juries. ${ }^{264}$

Other studies suggest that smaller groups encourage equality of participation. ${ }^{265}$ Lempert noted, however, that this difference is largely artifactual. Assuming that a six-person jury and a twelveperson jury deliberate for an equal number of hours, "the percentage participation of members of a larger group will always be less than the percentage participation of members of smaller groups, simply because there are more members [in the larger group] to share the time." ${ }^{266}$ However, simply calculating percentage participation time does not consider the quality of participation, or the more critical question of whether an individual has succeeded in making all the arguments she considered relevant. ${ }^{267}$ In the larger jury, probability of argument or fact repetition increases with the larger number of speakers. Thus, an individual's lower "percentage" of participation may also reflect the fact that her arguments or factual points have already been made. Hans Zeisel's and Shari Diamond's ${ }^{269}$ work further undercuts arguments suggesting that smaller juries encourage more equal participation by showing that jurors holding the minority opinion on twelve-person panels participate in a disproportionately large share of the deliberation. ${ }^{269}$

Summarizing the entire body of small-group research as extended to the jury, Lempert concluded that:

${ }^{264}$ See id. (citing a study for its conclusion that, in solving complex human-relations problems, groups of 12 and 13 were significantly better than groups of 6,7 , or 8 ). For further discussion of this study, see David J. Fox et al., Comparison of Decisions Written by Large and Small Groups, 8 AM. PSYCHOL. 351 (1953).

${ }^{265}$ See, e.g., L. Richard Hoffman, Group Problem Solving, in 2 ADVANCES IN EXPERIMENTAL SOCIAL PSYCHOLOGY 99, 99-127 (Leonard Berkowitz ed., 1965) (reviewing the literature on how groups use the resources of their members to solve problems, as well as which factors inhibit and which factors promote effective problem solving).

${ }^{266}$ Lempert, supra note 163, at 693.

${ }^{267}$ See id. at 694 .

${ }^{263}$ See Shari Seidman Diamond, A Jury Experiment Reanalyzed, U. MrCH. J.L. REFORM $520,525-27$ (1974) ("[T] he average participation of minority members [of a jury] exceeds the expected participation by a greater amount in twelve-member juries than in six-member juries.").

${ }^{269}$ See id; see also Lempert, supra note 163, at 694-95 (citing R. SIMON, THE JURY AND THE DEFENSE OF INSANITY 244 n.9 (1967) ("[C]ases in which all twelve jurors did not contribute at least one comment were unusual.")). 
the evidence is generally consistent and overwhelming. Current knowledge justifies the general conclusion that where the verdicts of six- and twelve-member juries diverge, the verdicts of twelve are likely to be of somewhat higher quality than the verdicts of six, and are likely to be superior with respect to other important values. ${ }^{2 \pi}$

\section{Community Representativeness and Impact of Minority Viewpoints}

Although "obtaining a representative cross-section of the community" ${ }^{\text {271 }}$ was, for the Williams Court, one of the central purposes of the jury, the Court concluded, without a scintilla of evidence, that "in practice the difference between the twelve-man and the six-man jury in terms of the cross-section of the community represented seems likely to be negligible."272 Subsequent research has proven the Court's speculation in this area to be erroneous. ${ }^{273}$

In an experiment comparing six- and twelve-person juries selected from the same population pool, Lempert illustrated that jurors on the larger panels more accurately represented the community from which the groups were drawn, and that the attitudinal characteristics of twelve-person juries more closely represented the average attitudinal characteristics of the pool. ${ }^{274}$ Between six and twelve-person juries, there was a substantial difference in the representation of jurors with minority attitudinal characteristics, racial identities, or perceptual viewpoints, as is illustrated below.

${ }^{270}$ Id. at 698 (emphasis omitted).

${ }^{271}$ Williams v. Florida, 399 U.S. 78, 100 (1970).

${ }^{272} I d$. at 102.

${ }^{273}$ See Lempert, supra note 163, at 668-79 (charting the significant differences in minority representation between six-and twelve-person juries); see also Dale W. Broeder, The Negro in Court, 1965 DukE L.J. 19, 23 (suggesting that in one case, the presence of one black juror on a jury prevented prejudicial voting effects).

${ }^{274}$ See Lempert, supra note 163 , at 668. 


\section{TABLE $1^{275}$}

Probabilities for Juries of Six and Twelve That No Juror Will Be Selected with a Characteristic Shared by Given Percentages of Individuals in the Population from Which the Jury Is Drawn

\begin{tabular}{|c|c|c|}
\hline $\begin{array}{c}\text { Percentage of individuals } \\
\text { sharing characteristics in } \\
\text { the population }\end{array}$ & $\begin{array}{c}\text { In six-member } \\
\text { juries }\end{array}$ & $\begin{array}{c}\text { In twelve-member } \\
\text { juries }\end{array}$ \\
\hline $55-100 \%$ & $0.00(0 \%)$ & $0.00(0 \%)$ \\
\hline $50 \%$ & $.016(2 \%)$ & $0.00(0 \%)$ \\
\hline $45 \%$ & $.028(3 \%)$ & $.001(0 \%)$ \\
\hline $40 \%$ & $.047(5 \%)$ & $.002(0 \%)$ \\
\hline $35 \%$ & $.075(8 \%)$ & $.006(1 \%)$ \\
\hline $30 \%$ & $.118(12 \%)$ & $.014(1 \%)$ \\
\hline $25 \%$ & $.178(18 \%)$ & $.032(3 \%)$ \\
\hline $20 \%$ & $.262(26 \%)$ & $.069(7 \%)$ \\
\hline $15 \%$ & $.377(38 \%)$ & $.142(14 \%)$ \\
\hline $10 \%$ & $.531(53 \%)$ & $.282(28 \%)$ \\
\hline $5 \%$ & $.735(74 \%)$ & $.540(54 \%)$ \\
\hline $0 \%$ & $1.00(100 \%)$ & $1.00(100 \%)$ \\
\hline
\end{tabular}

Thus, in a hypothetical jurisdiction where African-Americans constitute ten percent of the jury pool, more than half of six-person juries would fail to include an African-American member, compared to just over one quarter of twelve-person juries. Given that the presence of a single African-American on a jury could be significant both in inhibiting other jurors from expressing prejudicial opinions which could influence the deliberative process ${ }^{276}$ and in providing expertise regarding the "black experience" or certain cultural or

${ }^{275}$ Id. at 669 (parenthetical percentages added). These results exactly corroborate Zeisel's earlier (but more abbreviated) statistical findings. See Zeisel, supra note 163, at 716,720 (finding that, assuming a $10 \%$ minority population, $72 \%$ of twelve-member juries would have one minority member compared to $47 \%$ of six-member panels, and that the expectation of seating two minority members is $34 \%$ on a twelve-person jury compared to $11 \%$ on a six-person jury).

${ }^{276}$ See Lempert, supra note 163, at 670; see also Broeder, supra note 273 , at 23 (noting that evidence from post-trial juror interviews revealed that the presence of a black juror inhibited at least two other jurors from siding with a prejudicial faction). 
linguistic conventions unique to the African-American community, ${ }^{277}$ this finding is not "negligible" as the Williams Court suggested.

Although, theoretically, larger juries are more likely to include jurors with outlying antisocial viewpoints, most such viewpoints ${ }^{278}$ are sufficiently uncommon that they will very rarely infiltrate even larger juries. Potential jurors harboring such antisocial viewpoints might be challenged for cause during voir dire. Or, if seated on a jury, they might suppress entirely such viewpoints, given the normative unpopularity of such positions. ${ }^{279}$ Given the statistical rarity of such viewpoints in most jury pools, a "radical juror" would almost certainly stand alone, and would thus face the same pressures to conform discussed earlier. ${ }^{280}$

The conformity effects seen in the Sherif and Asch experiments can also be expected to appear in the jury context. ${ }^{281}$ Given what is known about the influence of group-conformity pressure, the presence of a minority juror or minority viewpoint on a jury, though

27 See Lempert, supra note 163, at 670 (noting that a "black juror [may] possess[] expertise that allows him to give other jurors important information"). Lempert suggested, for example, that a black juror might be uniquely qualified to explain, based on her life experience, why an innocent inner-city African-American youth might run from the police. See id.

${ }^{278}$ "Outlying antisocial viewpoints" might include such things as bigotry, antiSemitism, anarchism, and the like. See id. at 672-73.

${ }^{279}$ See id.; see also Baum, supra note 2, at 12-13 ("One of the virtues of the jury system is the canceling out of an individual juror's prejudices by offsetting predilections of other jurors .... Because the chances of ... heterogeneity are greater with the twelve-man jury, the bias-canceling process works more effectively with the larger jury.").

${ }^{280}$ See HARE, supra note 250, at 20 ("[The] process of modification of behavior may range from an individual's conscious attempts to conform to norms to the unconscious acceptance of group or individual directives."); Asch, supra note 186, at 189 (discussing "social and personal conditions that induce individuals to resort to or yield to group pressures"); Asch, supra note 251, at 31 (discussing the urge toward social conformity); Sherif, supra note 250, at 90 ("The introspections reveal that the subjects become conscious of the norm which develops in the course of the experiment.").

${ }^{281}$ See, e.g., Roper, supra note 163, at 986. Asch's research was an extension of Sherif's work. Although jury deliberations involve more ambiguous and more challenging problems than those posed by Sherif and Asch, the social-psychology literature suggests that such difficulty and ambiguity should only exacerbate the observed conformity effects. Lempert noted:

When a problem is clear, individuals probably feel that there is little to gain from knowing how others would resolve it... When evidence is ambiguous, individuals may be more willing to rely on the judgments of those who appear to find the evidence not ambiguous than would ordinarily be the case.

Lempert, supra note 163 , at 675 n.96. 
significantly more likely on a twelve-person jury than on a six-person jury, will be most influential only if that minority position is joined by an ally. ${ }^{282}$ As such, inquiries into the probability of "double-minority representation" on six-and twelve-person juries in a given population are of obvious relevance. Once again, the Lempert experiment is instructive:

\section{TABLE $2^{283}$}

Probability That At Least a Certain Number of Jurors with a Particular Characteristic Will Be Chosen When That Characteristic Is Shared by Given Percentages of the Population from Which Jurors Are Drawn

\begin{tabular}{|c|c|c|}
\hline $\begin{array}{c}\text { Percentage of } \\
\text { individuals sharing } \\
\text { characteristics in the } \\
\text { population }\end{array}$ & $\begin{array}{l}\text { Probability of drawing } \\
2 \text { or more out of } 6\end{array}$ & $\begin{array}{l}\text { Probability of drawing } \\
2 \text { or more out of } 12\end{array}$ \\
\hline $85-100 \%$ & $1.00(100 \%)$ & $1.00(100 \%)$ \\
\hline $80 \%$ & $.998(100 \%)$ & $1.00(100 \%)$ \\
\hline $75 \%$ & $.995(100 \%)$ & $1.00(100 \%)$ \\
\hline $70 \%$ & $.989(99 \%)$ & $1.00(100 \%)$ \\
\hline $65 \%$ & $.978(98 \%)$ & $1.00(100 \%)$ \\
\hline $60 \%$ & $.959(96 \%)$ & $1.00(100 \%)$ \\
\hline $55 \%$ & $.931(93 \%)$ & $1.00(100 \%)$ \\
\hline $50 \%$ & $.891(89 \%)$ & $.997(100 \%)$ \\
\hline $45 \%$ & $.836(84 \%)$ & $.992(99 \%)$ \\
\hline $40 \%$ & $.767(77 \%)$ & $.980(98 \%)$ \\
\hline $35 \%$ & $.681(68 \%)$ & $.953(95 \%)$ \\
\hline $30 \%$ & $.580(58 \%)$ & $.915(92 \%)$ \\
\hline $25 \%$ & $.466(47 \%)$ & $.842(84 \%)$ \\
\hline $20 \%$ & $.345(35 \%)$ & $.725(73 \%)$ \\
\hline $15 \%$ & $.224(22 \%)$ & $.557(56 \%)$ \\
\hline $10 \%$ & $.114(11 \%)$ & $.341(34 \%)$ \\
\hline $5 \%$ & $.033(4 \%)$ & $.118(12 \%)$ \\
\hline $0 \%$ & $0.00(0 \%)$ & $0.00(0 \%)$ \\
\hline
\end{tabular}

${ }^{223}$ Lempert, supra note 163, at 677 (parenthetical percentages added). 
As Table 2 illustrates, assuming the same ten-percent AfricanAmerican population in a given jury pool, a twelve-person jury jurisdiction would seat a "viable minority" ${ }^{284}$ in more than one-third of all trials, whereas a six-person jury jurisdiction would seat a viable minority only about one time in ten. Lempert's findings, resulting from a principled statistical analysis, ${ }^{285}$ pose a direct challenge to the Williams Court's wholly unsupported claim that "in practice the difference between the twelve-man and the six-man jury in terms of the cross-section of the community represented [is] likely to be negligible." 286

\section{Jury Size, Representation, and Outcome-Determinativeness}

The presence of a viable minority dyad has been experimentally shown to be sufficient to resist even a large opposing majority. ${ }^{287}$ If Asch's conformity theory holds, twelve-person juries should deliberate more vigorously, and hang "substantially more often" than six-person juries because of the increased frequency of viable minority positions on twelve-person juries. ${ }^{288}$ Harry Kalven, Jr. and Hans Zeisel had earlier realized this result in a purely comparative evaluation of a large sample of six- and twelve-person jury verdicts, finding that only $2.4 \%$ of the six-person juries hung, compared to $5.5 \%$ of the twelveperson juries. $^{289}$

${ }^{284}$ See Roper, supra note 163, at 987 (defining "viable minority" as a minority position supported by at least two jurors, and thus, capable of withstanding majority conformity pressure).

${ }^{285}$ Lempert's extended analysis corroborated Zeisel's earlier statistical analysis. See Zeisel I, supra note 163, at 716, 720.

${ }^{286}$ Williams v. Florida, 399 U.S. 78, 102 (1970).

${ }^{287}$ See Asch, supra note 251, at 34 (reporting that a minority comprised of more than one was more difficult to sway in an experiment); Lempert, supra note 163, at 678 (noting that a person with a minority position is more likely to withstand the group pressure of the majority if at least one other person shares the minority position); cf. Zeisel I, supra note 163, at 719-20 (noting that hung juries almost always occur when there are several original dissenters).

${ }^{283}$ See Lempert, supra note 163 , at 676 (asserting that twelve-person juries should hang more frequently than six-person juries if Asch's work is accurate).

${ }_{259}$ A statistical comparison was made between six-person jury verdicts culled from the Miami Circuit Court (Florida's largest court), and twelve-person jury results collected from a national sample. See KALVEN \& ZEISEL, supra note 163, at 56-57 (stating that twelve-person juries hang in $5.5 \%$ of all cases); Zeisel I, supra note 163, at 720 (reporting the percentages as $2.4 \%$ and $5.0 \%$, respectively). A discrepancy between results reported in The American Jury and Zeisel's later article quoting the book, Zeisel I, supra note 163, is apparently due to a misprint in the later article. See Lempert, supra note 163 , at $676 \mathrm{n} .99$ (noting the discrepancy between the $5.0 \%$ figure 
Although the validity of this finding was still largely in question at the time of Lempert's study, ${ }^{290}$ subsequent research has sufficiently corroborated the effect. ${ }^{291}$ Using a case developed to exhibit equated sets of empirically weighted facts in the prosecution's and defense's case, and sets of six- and twelve-person juries with no significant demographic differences, ${ }^{292}$ Angelo Valenti and Leslie Downing adjusted the factual evidence presented to the various juries to create two experimental conditions: one where six- and twelve-person juries were presented with a case that slightly favored the prosecution, and one where the different-sized juries were presented with a case that slightly favored the defense. ${ }^{299}$ Statistical analysis revealed that in the slightly pro-prosecution scenario, six-person juries convicted the defendant significantly more often than twelve-person juries. Although the standard in criminal cases requires that a jury be certain "beyond a reasonable doubt," results showed that where the empirically weighted facts were carefully designed to remain highly ambiguous and thus not beyond a reasonable doubt, the defendant was convicted nine out of ten times by six-person juries, but only two out of ten times by twelve-person juries. ${ }^{294}$

Valenti and Downing concluded that twelve-person juries were more sensitive to the "ambiguities in the case," conviction-seeking jurors found it impossible to sway other factions to convict the defendant on ambiguous evidence. Six-member juries,

in Zeisel's article and the $5.5 \%$ figure in Zeisel's earlier book and speculating that the discrepancy might be due to a misprint).

Although purely comparative in nature, the discrepancy in the percentage of hung juries between juries of different sizes recognized in Zeisel I is most likely accurate due to the large sample size. See id. (stating that it is unlikely that the discrepancy is due to a flaw in data collection or comparison).

${ }^{250}$ See Lempert, supra note 163, at 676 (citing only the Kalven \& Zeisel work in support of this premise).

${ }^{291}$ See SAKS, supra note 191, at 18 (asserting that smaller juries are less likely to hang); Kerr \& MacCoun, supra note 200, at 359 (reporting that six- and twelve-person juries differed significantly in hung-jury rates, with twelve-member juries hanging more often); Roper, supra note 163, at 990 ("[T]welve-member juries hang significantly more often than do smaller juries."); Valenti \& Downing, supra note 163 , at 274 (corroborating the predicted effect that reducing jury size from 12 to six would greatly increase conviction rates).

${ }^{292}$ See Valenti \& Downing, supra note 163, at 273 (describing the case as containing 25 facts favoring the prosecution and 25 favoring the defendant).

${ }^{293}$ Instrument-reliability analysis revealed that the evidence had been successfully manipulated between these two conditions such that each varied from neutral by the same degree. See id. at 274 (confirming the validity of the manipulation).

${ }^{291}$ See id. (providing a table which outlines the results of the experiment).

${ }^{295}$ Id. 
however, almost always convicted when presented with the same evidence, perhaps due to the increased group pressure in the smaller panels. ${ }^{296}$ Given that the "reasonable doubt" standard is a cornerstone of criminal law, Valenti and Downing's findings regarding jury size and conviction propensity are extremely significant.

In a subsequent study, Robert Roper suggested that a viable minority, much more common in twelve-person juries than in sixperson juries, affected jury behavior in one of three ways: (1) by refusing to conform to the majority position, thereby causing a hung jury; (2) by converting the "majority" to the minority viewpoint through additional deliberation caused by the minority's refusal to conform; or (3) by eventually conceding to the majority viewpoint after thorough deliberation. ${ }^{297}$ Consequently, Roper proposed four experimental hypotheses: (1) juries with viable minorities will hang more often than juries lacking viable minorities; (2) juries with viable minorities will show more inconsistency between their predeliberation propensities and their final verdicts due to the "persuasion effect" coupled with the viable minority's ability to withstand the majority's conformity pressure; (3) twelve-person juries, which are more likely to seat viable minorities, will hang more often than sixperson juries; and finally (4) since viable minorities are more likely to be seated on twelve-person juries, the final verdicts of twelve-person juries will show more variance from their predeliberation dispositions than will six-person juries. ${ }^{298}$

Roper corroborated well-established conformity findings ${ }^{299}$ and confirmed that viable minorities were significantly "more likely to cause juries to hang than [were] non-viable minorities." showed, however, that intense viable minority resistance could facilitate the breakdown of an initial majority consensus. ${ }^{301}$ The more vigorous deliberation process caused by the presence of the minority dyads allowed for a more complete examination of the case, which sometimes produced a shift in the majority opinion. Not surprisingly,

\footnotetext{
${ }^{206}$ See id. (noting a six-person jury's heightened susceptibility to group pressure).

${ }^{297}$ See Roper, supra note 163, at 987 (discussing the different possibilities that arise when a viable minority forms).

${ }^{298}$ See id. at $987-88$.

${ }^{299}$ See, e.g., Asch, supra note 251, at 34 (finding the presence of an ally to be the critical factor in an individual's ability to resist conformity pressure from the group majority).

${ }_{300}$ Roper, supra note 163 , at 988.

${ }^{301}$ See id. at 989 (referring to several cases in which viable minorities prevailed over initial majorities).
} 
however, such verdict shifts only occurred in juries with viable minorities. ${ }^{302}$ Finally, Roper confirmed that "twelve-member juries hang significantly more often than do smaller juries," ${ }^{303}$ a fact which he attributed directly to the ability of viable minorities to influence the deliberative process and resist conformity pressure from the majority. ${ }^{304}$

On the basis of these findings alone, twelve-person juries should be required in criminal cases, since at a minimum, twelve-person juries facilitate minority resistance to conformity pressure from the majority, promote a more vigorous deliberation of the issues, and deter immediate decisions in all but the most clear-cut cases. ${ }^{305}$ Larger juries recall more facts, and in the complex human-relations problems routinely faced by juries, provide a more thorough analysis of the relevant issues, viewed through a broader range of lenses. Although these deliberative differences do not always sway the majority decision, the research shows that the use of twelve-person juries provides significantly greater assurances that the jury will function in accordance with its fundamental purposes as established by the Court in Duncan and Williams.

A hung jury in a criminal trial favors the defendant because she remains unconvicted. ${ }^{306}$ Subsequently, charges may be dropped, ${ }^{307}$ there might be a renewed opportunity for plea-bargaining, and, at the very least, the defense has been fully exposed to the prosecution's case. $^{308}$ Given that a hung jury in a criminal case indicates at least some degree of reasonable doubt, however, these results hardly seem inappropriate. As long as our system of criminal justice is predicated

${ }^{902}$ See id. (noting that "[o]nly juries with viable minorities produced verdicts that were inconsistent with the group's predisposition").

${ }^{\text {sos }}$ Id. at 990 .

See id. (stating that the results were "primarily a function of the resistance ability of viable minorities").

${ }^{305}$ See id. at 992 (suggesting that larger juries "promote resistance to majority persuasion," engage in "extended discussion," and produce a "greater number of ideas").

${ }^{\text {sos }}$ See Kerr \& MacCoun, supra note 200, at 360 ("A hung jury is a relatively favorable outcome for the defendant."); Lempert, supra note 163, at 677 ("Hung juries generally aid defendants.").

${ }^{207}$ This result is common when the jury was leaning toward acquittal. See Lempert, supra note 163 , at 677 .

${ }^{309}$ See Kerr \& MacCoun, supra note 200, at 360 (noting that a hung jury "may lead to renewed plea bargaining"); Lempert, supra note 163, at 677 (pointing out that the defendant "has had discovery of the prosecution's case, and will often be in a better position to plea bargain"). 
on a theory of innocence until guilt is proven beyond a reasonable doubt, such results must be accepted as the product of a properly functioning criminal justice system. As the preceding research has illustrated, however, by permitting criminal juries to be reduced in size, the Williams Court has undermined the deliberative processes of the criminal jury in a way that reduces the thoroughness of deliberation and the possibility of hung juries, and quiets voices of reasonable doubt, potentially leading to more unjust convictions. These arguments will be taken up more completely in Part V of this Comment.

\section{Consistency and Reliability of Verdicts}

Lempert's research suggested that the verdicts of twelve-member juries, while "better" because of the greater inclusiveness and potential effect of minority viewpoints, also demonstrated more consistency across similar cases and often mirrored the prevailing decisions of the community at large. ${ }^{309}$ Zeisel also illustrated this consistency effect in the context of damage assessment in civil trials. ${ }^{310}$

In Zeisel's hypothetical civil-damages case tried before a jury composed of an entire community, the only dispute involved the appropriate level of damages. One-sixth of the community favored an assessment of $\$ 1000$, one-sixth favored $\$ 2000$, and similarly up to $\$ 6000 .^{311}$ A precise community compromise in this case would yield a damage assessment of $\$ 3500$. Zeisel showed, however, that when sixmember juries decided this case, only fifty-one percent of the verdicts arrived at the expected compromise between $\$ 3000$ and $\$ 4000$, while sixteen percent of the verdicts fell into the "haywire" either higher than $\$ 4500$ or lower than $\$ 2500$. In contrast, when twelve-member juries decided the case, sixty-eight percent of the verdicts fell between $\$ 3000$ and $\$ 4000$, while only four percent of verdicts landed in the outlier regions. ${ }^{313}$ Zeisel's experiment is yet another illustration that the twelve-member jury more consistently

${ }^{509}$ See Lempert, supra note 163 , at 679 (" [T] he statistical analysis indicates that twelve-member juries are more likely than six-member juries to contain individuals who represent minority groups and viewpoints.").

${ }^{310}$ See Zeisel I, supra note 163 , at 716-18 (noting that "the six-member juries show a considerably wider variation of 'verdicts' than the twelve-member juries").

${ }^{311}$ See id. (describing the experiment); see also Lempert, supra note 163 , at $680-81$ (same).

${ }^{312}$ Baum, supra note 2, at 12.

${ }^{313}$ See Zeisel I, supra note 163 , at 716-18 tbl.2. 
reflects the average viewpoint of the community.

Lempert has shown that the greater tendency of twelve-member juries to reflect the average judgment of the communities from which they are drawn suggests that verdicts of two different twelve-person juries, in distinct but similar cases, are also likely to be more consistent with each other than are the verdicts of two six-person juries. $^{314}$ Since our legal system "values the similar treatment of individuals in like circumstances, ${ }^{315}$ Lempert concluded that "if the community's judgment is the standard, the quality of decisions rendered by twelve is likely to be higher than the quality of those of six regardless of which party has the better case." ${ }^{316}$

\section{The Third Time Is Not a Charm: The Bungling of Ballew v. Georgia}

The Court again faced the jury-size question in Ballew $v$. Georgia, ${ }^{317}$ this time with a significant body of empirically and methodologically valid psychological research at its disposal. The Court was unanimous in its holding that five-person criminal juries were unconstitutional, but was sharply divided in its reasoning. Justice Blackmun's opinion revisited the Williams decision, explaining that:

By 1970 little empirical research had evaluated jury performance.... [T] he Court found no evidence that the reliability of jury verdicts diminished with six-member panels. Nor did the Court anticipate significant differences in result, including the frequency of "hung" juries.... [C]oncern that the representative or cross-section character of the jury would suffer with a decrease to six members seemed an "unrealistic one." As a consequence, the six-person jury was held not to violate the Sixth and Fourteenth Amendments.

Justice Blackmun acknowledged, however, that since Williams, a "quantity of scholarly work on jury size had been generated." "\$19 Referring to these post-Williams studies, ${ }^{320}$ Justice Blackmun noted

S14 See Lempert, supra note 163, at 681 (suggesting that "damages awarded by two different juries to two plaintiffs suffering similar injuries are likely to be closer in amount if the juries each have twelve members than if they each have six").

${ }^{313} I d$.

${ }^{316} I d$. at 684.

917435 U.S. 223 (1978) (plurality opinion).

${ }^{318}$ Id. at 230 (plurality opinion) (citations omitted).

s19 Id. at 231 (plurality opinion).

${ }^{320}$ See id. at 231-39 nn.10-32 (plurality opinion) (cataloging the studies the Court examined in reaching its decision-studies which included much of the work of Lempert, Zeisel, Saks, and Asch discussed supra Part IV.C.I-4). 
that:

We have considered them carefully because they provide the only basis, besides judicial hunch, for a decision about whether smaller and smaller juries will be able to fulfill the purpose and functions of the Sixth Amendment. Without an examination about how juries and small groups actually work, we would not understand the basis for the [argument against the use of smaller juries].

The plurality opinion provided a well-documented, updated review of the psychology literature and drew five sufficiently corroborated conclusions. ${ }^{322}$

First, the plurality admitted that proper empirical data revealed that smaller juries were less likely to foster effective group deliberation and might lead to "incorrect application of the common sense of the community to the facts." ${ }^{323}$ The plurality recognized that "[a]s juries decrease in size ... they are less likely to have members who remember each of the important pieces of evidence or argument," ${ }^{324}$ and are "less likely ... to overcome the biases of [their] members to obtain an accurate result. ${ }^{\text {,325 }}$

Second, the plurality observed that "the data now raise doubts about the accuracy of the results achieved by smaller and smaller panels. ${ }^{326}$ The plurality also suggested that smaller juries have a greater propensity to convict. ${ }^{327}$

Third, the plurality found that "the data suggest that the verdicts of jury deliberation in criminal cases will vary as juries become

${ }^{321}$ Id. at $232 \mathrm{n} .10$ (plurality opinion).

${ }^{322}$ See Grofman, supra note 163, at 289 (noting that Blackmun's opinion was, according to one scholar, the most extensive use of social science ever made by the Court); Tanke \& Tanke, supra note 43, at 1132 ("The lead opinion included a ... welldocumented discussion of legal and social scientific literature ...").

${ }^{223}$ Ballew, 435 U.S. at 232 (plurality opinion).

${ }^{324} I d$ at 233 (plurality opinion).

${ }^{325}$ Id (plurality opinion).

${ }^{326} I d$. at 234 (plurality opinion).

${ }^{327}$ See id. (plurality opinion) ("Statistical studies suggest that the risk of convicting an innocent person ... rises as the size of the jury diminishes."). Blackmun cites the findings of Stuart Nagel and Marian Neef, Deductive Modeling to Determine an Optimum Jury Size and Fraction Required to Convict, 1975 WASH. U. L.Q 933, for this conclusion. While this study's initial assumptions have been deemed questionable, later research has corroborated findings of increased conviction propensity in smaller juries. See, e.g., Roper, supra note 163, at 979 ("Blackmun's opinion was unusual in its synthesis of, and reliance upon, social science studies of jury size. It was, in fact, largely accurate .... "); Valenti \& Downing, supra note 163, at 274 (noting that six-person juries "are far more efficient" in reaching convictions than twelve-person juries). For a complete treatment of this issue, see supra notes 163-200 and accompanying text. 
smaller, and that the variance amounts to an imbalance to the detriment of one side, the defense." ${ }^{\text {228 }}$ The plurality recognized that as jury size decreases, the opportunity for viable minority dyads to be seated on those juries also decreases, reducing the chance of a hung jury, and resulting in more convictions. ${ }^{329}$

Fourth, the plurality recognized that decreases in jury size "foretell[] problems not only for jury decisionmaking, but also for the representation of minority groups in the community. ${ }^{\text {sso }}$ Justice Blackmun's opinion cited the Court's history of protecting minority representation on juries and invoked the language of Smith $v$. Texas ${ }^{331}$ and Strauder $v$. West Virginia. ${ }^{332}$ The plurality concluded that "the opportunity for meaningful and appropriate representation does decrease with the size of the panels.. ${ }^{335}$

Fifth, the plurality recognized that prior research showing no differences between six- and twelve-person juries was methodologically flawed, and that later research had shown that important disparities exist between the two juries. ${ }^{334}$ The plurality noted that:

Nationwide ... these small percentages will represent a large number of cases. And it is with respect to those cases that the jury trial right has its greatest value. When the case is close, and the guilt or innocence of the defendant is not readily apparent, [we rely on] a properly functioning jury system [to] insure evaluation by the sense of the community and [to] insure accurate factfinding.

On the basis of this language, and with the strength of so much empirical evidence behind it, it seemed that the Ballew plurality was

${ }^{\text {923 }}$ Ballew, 435 U.S. at 236 (plurality opinion) (discussing studies embracing group theory conducted by Asch, supra note 163; Lempert, supra note 163; and Zeisel I, supra note 163).

${ }^{329}$ See id. (plurality opinion) ("As the numbers diminish below six, even fewer panels would have one member with the minority viewpoint and still fewer would have two. The chance for hung juries would decline accordingly.").

${ }^{350} I d$.

s31 311 U.S. 128, 130 (1940) ("It is part of the established tradition in the use of juries as instruments of public justice that the jury be a body truly representative of the community.").

${ }_{932} 100$ U.S. 303, 308 (1880) (noting that exclusion of minority elements of the community contravenes " $[t]$ he very idea of a jury ... composed of the peers or equals of the person whose rights it is selected or summoned to determine.").

s9s Ballew, 435 U.S. at 237 (plurality opinion).

ss4 See id. (plurality opinion) (noting that "several authors have identified in jury research methodological problems tending to mask differences in the operation of smaller and larger juries").

${ }^{335}$ Id. at 237-38 (plurality opinion). 
finally prepared to overrule its decision in Williams. Instead, the Court made yet another interpretive error, and again failed to mandate twelve-person juries. ${ }^{336}$ Despite drawing the five proper conclusions just described, the Court used the results of these studies comparing six- and twelve-person jury function to proscribe five-person juries. ${ }^{337}$ The Ballew holding left untouched the six-person criminal juries which were condemned by the very studies the Court relied upon to reach its decision. ${ }^{338}$ Without explanation or any attempt at justification, the Ballew plurality misapplied the conclusions of the entire body of social-science research it had taken such pains to interpret properly, and by doing so, failed for the third time to reach the conclusions the research demanded. The decision prompted frustrated researchers to conclude that " $[\mathrm{t}]$ he quality of social science scholarship displayed in [the Court's] decisions would not win a passing grade in a high school psychology class, ${ }^{n 39}$ and prompted angry referral to the Court's reasoning as "perverse[]" and making "no pretense at logic.."

Although the Ballew Court was unanimous in ruling that panels smaller than six in nonpetty state criminal trials were unconstitutional, there was little agreement on rationale. ${ }^{341}$ Only Justice Stevens joined Justice Blackmun in relying on the aforementioned socialscience findings. Three Justices-Powell, Burger, and Rehnquist-

${ }^{836}$ The Court's first error occurred in Williams, where it relied on six nonempirical studies to dismantle first the twelve-person jury requirement. See Williams v. Florida, 399 U.S. 78, 101 \& n.48 (1970) ("What few experiments have occurred... indicate that there is no discernible difference between the results reached by the two different sized juries.") The second mistake occurred in Colgrove, where the Court relied on four deeply flawed empirical studies to reaffirm Williams. See Colgrove v. Battin, 413 U.S. $149,159 \&$ n.15 (1973) ( $[$ [F]our very recent studies have provided convincing empirical evidence of the correctness of the Williams conclusion ....").

${ }^{337}$ See Ballew, 435 U.S. at 239 (plurality opinion) (" $[$ We] conclude that the purpose and functioning of the jury in a criminal trial is seriously impaired, and to a constitutional degree, by a reduction in size to below six members.").

${ }^{33 s} \mathrm{See} i d$. (plurality opinion) (" $[W] \mathrm{W}$ adhere to, and reaffirm our holding in Williams $v$. Florida...."). This is a holding inconsistent with the plurality's reasoning that " [1]arger juries (size twelve) are preferable to smaller juries (six). They produce longer deliberations, more communication, far better community representation, and, possibly, greater verdict reliability.... [This] supports the conclusion that further reduction in jury size threatens Sixth and Fourteenth Amendment interests." Id. at 242 (plurality opinion) (quoting SAKS, supra note 191, at 107).

${ }^{3 s 9}$ Saks, supra note 1 , at 18.

${ }^{340}$ Roper, supra note 163 , at 979.

341 See id. (discussing the Court's unanimous holding in Ballew regarding juries of fewer than six members, and noting that "there was no agreement on a common opinion."). 
actually ridiculed the definitive conclusions of social science as untested "by the mechanism of the adversary process" ${ }^{342}$ and escalated the controversy between the Court and social-science scholars by dismissing the entire field of research on jury size as "numerology." Neither of these facts, however, sufficiently explains how the body of research the Court depended on in deciding Ballew became the basis for upholding the constitutionality of six-person juries. ${ }^{344}$

\section{THE PRACTICAL QUESTION: SAVING TIME AND MONEY}

Jury selection typically involves a two-step process-voir dire of an entire jury pool and subsequent selection of individual jurors. William Pabst noted that careful analysis had been conducted on cases heard in the United States District Court for the District of Columbia comparing the time and the costs of trials heard by twelveperson juries with those heard by six-person juries. ${ }^{345}$ Data revealed "virtually no reduction in time spent to impanel a jury or to try a case when the six-man jury is used." This finding casts considerable doubt on scholars' speculations that a reduction in jury size would "permit a substantial savings of time for the courts and court personnel." ${ }^{347}$ Pabst found that, in practice, eight jurors were generally selected for six-member panels, and fourteen were almost always seated on twelve-member panels, ${ }^{348}$ but the number of

${ }^{342}$ Ballew, 435 U.S. at 246 (Powell, J., concurring in judgment).

${ }^{343} I d$. (Powell, J., concurring in judgment). "Numerology," of course, is the study of the occult significance of numbers. See THE AMERICAN HeRTTAGE DICTIONARY OF THE ENGLISH LANGUAGE 1242 (3d ed. 1992).

${ }^{344}$ See Roper, supra note 163, at 979 ("No research was cited-none is availablewhich distinguished between five- and six-member juries.").

${ }^{315}$ See William R. Pabst, Jr., Statistical Studies of the Costs of Six-Man Versus Twelve-Man Juries, 14 WM. \& MARY L. REV. 326, 327 (1972) (outlining the methodology used in conducting the study comparing six-and twelve-person juries).

${ }^{346}$ Id. Pabst noted that outliers in the data involving juries of both sizes were excluded from the analysis-a common practice used to avoid distortion of the averages. See id. at n.7.

${ }^{317}$ Andrew W. Bogue \& Thomas G. Fritz, The Six-Man Jury, 17 S.D. L. REV., 285, 288 (1972). Bogue and Fritz suggested that six-person juries would "obviously take less time to notify, call, impanel, interrogate, and otherwise manage .... It would take less time to poll six jurors and six jurors could examine exhibits in less time during trial." Id.

${ }^{348}$ Two alternates were selected in each to hear the case in the event that the regular jurors needed to be replaced during trial. Alternates, however, do not take part in the deliberations unless they are called upon to replace regular jurors. See Pabst, supra note 345 , at 328. 
challenges was virtually identical for six- and twelve-person juries. ${ }^{349}$

Although there was no savings in time, the savings in cost were significant. Pabst calculated a $41.9 \%$ savings between trials using sixand twelve-person juries. ${ }^{350}$ Andrew Bogue and Thomas Fritz, ardent advocates of reducing jury size, ${ }^{351}$ estimated that, in 1972, maintaining the right to trial by a twelve-person jury cost South Dakota taxpayers thirty-five cents each per year. They further estimated that juries of six would cut the cost in half. ${ }^{352}$

Lempert suggested, however, that any attempt to balance the fiscal efficiency gained by the use of six-person juries against the functional costs of using the smaller juries was an imperfect and reckless practice. ${ }^{353}$ Lempert questioned whether the Sixth Amendment even allowed such a tradeoff of a defendant's rights, concluding that "the savings of the smaller jury are quite likely outweighed by the costs, some of which we may never measure. ${ }^{\$ 34}$

\section{CONCLUSION}

The time is right to revisit the Court's decisions in Williams and its progeny. The suburban creep of crime and the daily reports of violence on the nightly news have put much of the country in a prosecutorial mood. The recent, highly publicized trials of Rodney King and O.J. Simpson have returned issues of minority representation on juries and the proper function of the deliberative process to the forefront of the nation's collective consciousness.

The Court in Williams defined the jury's essential goals: "to promote group deliberation, free from attempts at intimidation, and to provide a fair possibility for obtaining a representative cross-section

${ }^{349}$ See id. ("Surprisingly, the number of challenges is almost as large for the sixman as for the twelve-man jury.").

${ }^{550}$ Pabst's formula multiplied the average panel size (generally 8 or 14) by voir dire time plus jury size multiplied by overall trial time to generate the overall time expended. Average six-person juries expended 77.3 hours of effort per trial, while average twelve-person juries expended 133.1 hours. See id.

${ }^{351}$ See Bogue \& Fritz, supra note 347 , at 290 ("We ... have a duty to seek new and better methods of judicial administration. The adoption of six-man juries ... is one way of increasing court efficiency and at a substantial financial savings to both state and federal governments ....").

${ }^{352}$ See id.

${ }^{353}$ See Lempert, supra note 163 , at 699 (noting that "the final judgment on six versus twelve will turn on the values that individuals subjectively place on minority views in the jury room").

${ }^{354}$ Id. 
of the community." ${ }^{355}$ The Court's primary considerations in contemplating departure from the twelve-person standard were: the reliability and representative makeup of the smaller jury; the effectiveness of the deliberative processes; the minority's ability to resist majority pressure; and the likelihood that a smaller jury would favor one side over the other. ${ }^{356}$

The Court displayed a surprising degree of unfamiliarity with the nature of social-science research, first by relying on six nonempirical studies in Williams, and then by relying on four flawed studies in Colgrove. Although little properly conducted research was available at the time these cases were decided, this does not excuse the Court's reliance on this research to support its conclusions. As Saks noted, very modest expertise would have been required to discredit the studies the Court relied on in Williams and Colgrove. ${ }^{357}$ This suggests that some other motivation might explain the "remarkable incompetence ${ }^{\$ 58}$ of these decisions.

The Court's decision three years earlier in Duncan reveals just such a motive. The Duncan Court, in holding that the Sixth Amendment right to trial by jury applied to the states via incorporation into the Fourteenth Amendment, ruled that:

The test for determining whether a right extended by the Fifth and Sixth Amendments with respect to federal criminal proceedings is also protected against state action by the Fourteenth Amendment has been phrased in a variety of ways, ... . [including] whether a right is among those "fundamental principles of liberty and justice which lie at the base of all our civil and political institutions ...." Because we believe that trial by jury in criminal cases is fundamental to the American scheme of justice, we hold that the Fourteenth Amendment guarantees a right of jury trial in all [state] criminal cases which-were they to be tried in a federal court-would come within the Sixth Amendment's guarantee.

In a series of decisions preceding the incorporation of the Sixth Amendment into the Fourteenth Amendment in Duncan, the Court announced that the jury contemplated by the Sixth Amendment was a jury "constituted, as it was at common law, of twelve persons, neither more nor less. ${ }^{\$ 60}$ Three years after Duncan, Williams presented what

${ }^{935}$ Williams v. Florida, 399 U.S. 78, 100 (1970).

${ }^{356}$ See id. at 100-02 \& nn.47-49.

357 See Saks, supra note 1, at 19.

sss Id.

${ }^{359}$ Duncan v. Louisiana, 391 U.S. 145, 148-49 (1968) (citation omitted).

${ }^{50}$ Thompson v. Utah, 170 U.S. 343, 349 (1898), overruled on other grounds by Collins v. Youngblood, 497 U.S. 37 (1990). 
many thought would be an easy question with an obvious resultnamely, that the Court would require the states to use twelve-person juries. The Court, however, faced a dilemma. If it stood by its earlier decisions and incorporated the twelve-person jury into the Fourteenth Amendment, it would have been treading near the frontier of its constitutionally granted powers-in effect requiring state legislatures to fund twelve-person juries for all nonpetty state criminal cases. ${ }^{361}$ If the Court deferred to federalism concerns, however, it would be forced to write a decision blatantly inconsistent with its own precedent, uprooting almost eight hundred years of common-law tradition.

It is interesting to question what might have happened had Williams come before the Court prior to the Court's ruling in Duncan. In the words of Justice Harlan's concurrence, the Court "strangely [did] an about-face.... that before... would have been unthinkable., ${ }^{362}$ The Williams Court's otherwise inexplicable disregard of stare decisis and historical precedent for the twelve-person jury and blatant misuse of "social science" evidence must have been prompted by a desire to avoid fettering the states as required by Duncan.

The benefit of a quarter-century of additional research and the clarity of hindsight enables us to conclude that Williams, Colgrove, and Ballew were wrongly decided. As the Ballew Court admitted, ${ }^{363}$ we now know that six- and twelve-person juries are not functionally equivalent, as the Williams Court assumed. ${ }^{364}$ We know that recall of facts, testimony, and in-court observations are compromised significantly when a six-person jury is used in place of a twelve-person jury. We know that the rate of hung juries declines and the rate of conviction rises when smaller juries are used. We know that minority representation, community representativeness, and quality of deliberation all decrease when six-person juries are used. Finally, we know that six-person juries are less reliable than twelve-person juries,

${ }^{361}$ See Williams, 399 U.S. at 130 (Harlan, J., concurring in judgment) ("'[I]f the Court is prepared to relax [federal] standards in order to avoid unduly fettering the States, this would be in derogation of ... standards in the federal system.' ) (alteration in original) (quoting Ker v. California, 374 U.S. 23, 45-46 (1963) (Harlan, J., concurring)).

${ }^{362}$ Id. at 122 (Harlan, J., concurring in judgment).

36s See Ballew v. Georgia, 435 U.S. 223, $232-37$ (1978) (plurality opinion) (stating the empirically demonstrated differences between six- and twelve-person juries).

${ }^{364}$ See Williams, 399 U.S. at 102 ("II]n practice the difference between the 12-man and the six-man jury in terms of the cross-section of the community presented seems likely to be negligible."). 
because they are less consistent in rulings on similar cases and because they decide all cases at greater variance from larger community preferences.

These findings have been sufficiently replicated and now represent the views of a majority of social-science scholars. Both the patent concerns about social science as "numerology" in Ballew, ${ }^{365}$ and the latent concerns about incorporation and federalism have lost their vigor. The Court has relied on social science much more actively since the time when these cases were decided, ${ }^{366}$ while the battle over incorporation of the Bill of Rights has long since been won. ${ }^{367}$

Williams and its progeny also gave rise to practical problems plaguing the criminal-justice system, chief among them being the use of jury size as a bargaining chip in plea-bargaining negotiations. Given the ability to depart from the twelve-person jury "requirement" with the consent of the defendant now provided by many state statutes, ${ }^{368}$ prosecutors who know the functional differences of these juries have bargained in exchange for the defendant's waiver of his right to a twelve-person jury. ${ }^{369}$ It is unlikely that either the Framers or the Court intended a criminal defendant's right to "trial by jury" to become an element of currency in prosecutorial bargaining.

Further, in a series of decisions culminating in Batson $v$. Kentucky, ${ }^{370}$ the Court attempted to maintain racial equality in the courtroom. Research has demonstrated, however, that by allowing smaller juries to be impaneled, the Court has opened a loophole which might allow racially motivated prosecutors to circumvent this line of jurisprudence and reduce or even completely eliminate

${ }^{365}$ See Ballew, 435 U.S. at 246 (Powell, J., concurring in judgment).

${ }^{265}$ See, e.g., LAWRENCE S. WRIGHTSMAN, PSYCHOLOGY AND THE LEGAL SYSTEM 26, 47 (4th ed. 1998) (summarizing the increased role of psychology in the law).

${ }^{367}$ The Court should no longer be concerned about financially burdening state legislatures in violation of the federalism doctrine. Other Court decisions involving Bill of Rights provisions reveal that placing additional financial burdens on state legislatures is not a concern when imposing important individual-rights guarantees on the states via the Fourteenth Amendment. Furthermore, regardless of the financial savings achieved by a reduction in jury size, it is difficult, if not impossible, to put a price on the liberty that provides the counterweight in this interest-balancing.

s6s See supra notes 148, 150.

${ }^{969}$ See State v. Griffith, 561 So. 2d 528, 529 (Fla. 1990) ("[T] he state waived the death penalty in exchange for an agreement with Griffith's counsel that Griffith would waive a twelve-person jury and be tried instead before a six-person jury."). For further discussion of this problem, see supra note 149 and accompanying text.

${ }^{370} 476$ U.S. 79 (1986) (disallowing racially based peremptory challenges). 
minorities or minority influence from their juries. This potential result of Williams and its progeny stands in direct opposition to the Court's policy stance taken in Batson. ${ }^{371}$

Given that the body of social science comparing six- and twelveperson juries directly implicates what the Williams Court labeled the "essential feature[s]" ${ }^{872}$ of a jury, a state criminal defendant, facing a six-person jury, might now be able to bring a legitimate Sixth Amendment challenge that the jury she faces is not a "jury" as contemplated by the Constitution. ${ }^{373}$ Such a claim now could succeed on the grounds that the aforementioned problems with the use of sixperson juries effectively compromise a criminal defendant's "fundamental [Sixth Amendment] right" ${ }^{\mathrm{s74}}$ to trial by jury, given the Williams Court's statement of what such juries must provide. ${ }^{375}$

Given what is now known about the functional differences of sixand twelve-person juries, particularly in the areas of community representation, reliability and consistency of verdicts, conviction rates, and deliberation quality, a criminal defendant's right to trial by a twelve-person jury should be "implicit in the concept of ordered liberty," ${ }^{376}$ and "fundamental to the American scheme of justice. ${ }^{377}$

The reversal of Williams and its progeny should not be barred by stare decisis. The Court has noted that stare decisis is a "principle of

${ }^{371}$ See supra notes 274-86 and accompanying text (illustrating how a reduction in jury size could reduce the influence of, or even completely eliminate, minorities from jury panels).

${ }_{372}$ Williams v. Florida, 399 U.S. 78, 100 (1970).

${ }^{373}$ See, e.g., Opinion of the Justices, 431 A.2d 135, 136-37 (N.H. 1981) (noting that the New Hampshire legislature has no power to depart from the twelve-person jury standard because "no body of less than twelve men, though they should be by law denominated a jury, would be a jury within the meaning of the [New Hampshire] constitution; nor would a trial by such body, though called a trial by jury, be such, within the meaning of that instrument... especially in light of the number of empirical studies that have questioned the impact of the six-member jury on our court system." ) (quoting Opinion of the Justices, 41 N.H. 550, 552 (1860)).

${ }^{374}$ Duncan v. Louisiana, 391 U.S. 145, 149 (1968).

${ }^{375}$ See Williams, 399 U.S. at 100.

${ }^{376}$ Palko v. Connecticut, 302 U.S. 319, 325 (1937) (defining "fundamental rights").

${ }^{377}$ Duncan, 391 U.S. at 149 . The Court has recently taken steps to ensure the community representativeness of criminal juries by proscribing race-based peremptory challenges, see Batson v. Kentucky, 476 U.S. 79, 84 (1986), and gender-based peremptory challenges, see J.E.B. v. Alabama, 511 U.S. 127, 129 (1994). 
policy," ${ }^{378}$ not an "inexorable command," overruled governing cases that were "badly reasoned." has expressed a willingness to overrule its decisions, despite the doctrine of stare decisis, when the passage of time brings its prior mistakes to light. This principle is especially true when the earlier misjudgments 'contradicted an 'unbroken line of decisions,' [and] contained 'less than accurate' ... analysis.. ${ }^{381}$ In re-examining prior holdings, the Court may ask "whether the facts have so changed or [have] come to be seen differently as to have robbed the old rule of significant application or justification.. ${ }^{382}$ There can be little doubt, based on the additional information now available, that this is the case with Williams, Colgrove, and Ballew.

Instructively, the Federal Rules of Criminal Procedure Advisory Committee did not amend their jury-size regulation after Williams. ${ }^{383}$ Rule 23(b) continues to require that "[j] uries shall be of twelve" for all criminal cases heard in federal court, subject to waiver by the defendant. ${ }^{384}$ Moreover, a subcommittee of the Judicial Conference is considering an amendment to the Federal Rules of Civil Procedure that would guarantee the right to a twelve-member jury in all civil cases tried in federal court. ${ }^{385}$ Since such an amendment would ultimately have to be approved by the Supreme Court, the Court's re-

${ }^{578}$ Helvering v. Hallock, 309 U.S. 106, 119 (1940); see also id. (explaining the rationale for overruling its decisions despite the doctrine of stare decisis).

${ }^{379}$ Payne v. Tennessee, 501 U.S. 808, 828 (1991); see also id. (noting that especially in constitutional cases, where Congress cannot easily remedy the Court's error, stare decisis should not deter the Court from overruling prior cases).

IN. at 827 .

${ }^{231}$ United States v. Dixon, 509 U.S. 688, 711 (1993) (quoting Solorio v. United States, 483 U.S. 435, 439, 442 (1987)); see id. (overruling an earlier double jeopardy case because of faulty historical analysis). Recall that the Court had stated directly that the Sixth Amendment right to trial by jury contemplated a jury of 12 in a number of decisions prior to Williams. See supra note 28 and accompanying text.

${ }_{\text {s92 }}$ Planned Parenthood v. Casey, 505 U.S. 833, 855 (1992) (citation omitted); see id. (noting that when considering whether to overrule an earlier precedent, the Court's judgment is "informed by a series of prudential and pragmatic considerations designed to test the consistency of overruling a prior decision with the ideal of the rule of law, and to gauge the respective costs of reaffirming and overruling a prior case").

${ }^{\text {ses }}$ See FED. R. CRIM. P. 23(b) (stating that courts can proceed constitutionally with less than 12 jurors, instead of declaring a mistrial, only if "one of the jurors is seriously incapacitated or otherwise found to be unable to continue" after the jury has commenced deliberations and alternate jurors have been dismissed).

ss Id. Departure from the twelve-person jury requires a written waiver from both parties and the approval of the judge.

See supra note 11 and accompanying text. 
examination of the entire line of jury-size cases, starting with Williams, may lie just beyond the horizon.

With the evidence now available about the functional nonequivalence of six- and twelve-person juries, it is clear that Williams, Colgrove, and Ballew have no remaining logical foundation. ${ }^{387}$ Whether the next jury-size challenge comes by way of the Judicial Conference, or in a Sixth Amendment challenge from a state criminal defendant, there can be only one justifiable result: On its next opportunity, the Supreme Court must bear the responsibility to return all nonpetty state criminal juries to a consistent twelve-person standard.

ss6 Although the Court could approve the amendment without implicating Colgrove, if such an amendment is passed by the Judicial Conference, it no doubt will be accompanied by a legislative history including many of the arguments made here. It seems unlikely, if such an amendment is passed by a committee which includes some of the best legal minds in the country, that the Court would fail to reexamine its own position on the matter.

${ }^{387}$ While the limits of this Comment preclude a thorough examination of the question of nonunanimous verdicts, much of the social-science analysis is clearly applicable to that question as well. It is easy to see how even a nine-to-three split, as allowed by Apodaca, see supra note 42, disempowers viable minority factions, greatly limits jury deliberation, and eliminates all but the most divided of hung juries. As a result, Zeisel labeled the allowance of the nonunanimous verdict "[size] reduction with a vengeance." Zeisel I, supra note 163, at 722. 